\title{
Evaluation of Economic Transformation in Hungary
}

\section{Libor Žídek ${ }^{1}$}

\begin{abstract}
The paper analyses transformation process in Hungary between 1989 and 2004. The goal of this paper is to analyze and evaluate the transformation process in Hungary. The structure of the paper follows this general goal. First of all, an analysis of economic development of the country before the fall of the communist regime is carried out because this determined the whole process which followed. Then we shortly mention political development that had a significant impact on the transformation process and its results. In the next part we concentrate on the main steps in the economic transformation, and consequently we devote space to specific aspects privatization, for example. The main economic indicators of this period are analyzed in the final part. We conclude that the transformation process achieved its main economic goal and the economy's ability to grow increased. At the same time, however, the transformation process created environment for the subsequent economic problems.
\end{abstract}

Key words: Hungary, economic transformation, economic growth

JEL Classification: P2, N14

\section{Introduction}

The goal of this paper is to analyze and evaluate the transformation process in Hungary. In the author's opinion, the main goal of the transformation process was a shift in the paradigm of the economy from the centrally planned system to a form of a market economy. In our view, this goal was generally reached with the accession to the EU. This is why we limit our paper to the period ending with 2004. We consider it an indirect proof that the environment reached a well-functioning market economy (formally it is a condition of the accession). The interesting question is how this state was achieved. We should not take it for granted because we can see several transforming countries that are still quite far from the state of a well-functioning market economy (for example Belarus). A shift in the overall trend of the economic development was the second goal of the transformation process, a more specific one, in our view. The centrally planned economy was doomed to fail - economic growth was declining and in fact negligible in the 1980s. As a consequence, the Hungarian economy was lagging behind the market economies. Any change of the pattern of the economy without improving its growth ability would be worthless. The paper tries to evaluate the progress from this point of view.

We see the process of the change as highly interesting. One of the reasons is that the country needed to overcome many obstacles on the way to become a market economy. For example, it suffered from numerous imbalances in the middle of the first

\footnotetext{
${ }^{1}$ Department of Economics, Faculty of Economics and Administration, Masaryk University, Lipová 41a, 60200 Brno, Czech Republic, email: zidek@econ.muni.cz
} 
transformation decade. The situation was critical, and in some aspects similar to the contemporary situation in Greece. The steps that were taken when dealing with the crisis could be seen as an example for the contemporary problems as well. Generally, we believe that we can always learn from history and the transformation process offers a much interesting experience and a lot of ideas.

We will start by describing the long-run political development in Hungary, which had an impact on the state of the Hungarian economy at the end of the 1980s, which is analyzed in the second chapter. In the next step we will concentrate on the political development during the transformation era, for which we consider the period between 1990 and 2004 (the accession to the EU). We believe that the accession to the EU can be seen as a proof of the state of the Hungarian economy. The main economic development is analyzed in the 3 following chapters. We concentrate on the sequence of the reforms first of all. Then the privatization development is examined in a stand-alone block. These two chapters describe the main economic steps. Then, in the last chapter, we sum up economic results in the studied period. In specific subchapters, economic growth, structure of the economy, inflation, unemployment and external relationship are analyzed.

We would like to point out that while working on the paper, we were confronted with troubles regarding data. Primarily, there were problems with length of consistent data series because it was highly difficult to find relevant and homogenous data that would cover the whole transformation period. As a consequence, we were forced to use shorter series. The data that we use are in our view the best that could be obtained.

And we would like to mention that there are data for the Czech Republic (Czechoslovakia) or Poland in some charts or tables. The primary goal of this article is not comparison, and these data should only help the reader to see the Hungarian process in a broader context. The Czech Republic and Poland are generally used as benchmarks for development.

\section{Long-run Political Development}

This text focuses on development during the transformation process but it is necessary to see Hungary in a broader prospect to understand it better. The long-run economic development has deep roots in our point of view. The key event was the consequence of the First World War. Hungary lost important part of its land to successor states of the Austro-Hungarian Empire and large Hungarian minorities found themselves in the neighboring countries - Czechoslovakia, Romania and Yugoslavia. It was deemed by Hungarians as totally unjust. The main goal of Hungarian diplomacy in the interwar period was unifying all Hungarians into a single state, or in other words to recreate large Hungary. The way to achieve this goal was in cooperation with fascist Germany in the 1930 s - and Hungary became Germany's ally during the war.

As a consequence, we can hardly talk about "liberation" of Hungary by the Red Army at the end of the war. Anyway, Hungary fell into the zone of the Soviet influence. And the communists (Hungarian Workers' Party) managed to establish a Soviet-style regime in 1949. But Hungarians were among the first that with force stood up against their regime during the riots of 1956. This uprising was bloodily suppressed by the Soviet troops but even the communist establishment understood that an important part of the Hungarian 
society disliked the regime. János Kádár (1912-1989) became the leader of the collaborationist government after the uprising. His government first of all harshly suppressed its opponents but in the 1960s started to relax the political and economic environment. Due to this, the regime is sometimes called "goulash socialism" (Kornai, 1996), which means a situation where people are generally willing to accept the regime in exchange for a more open economy (foreign goods) and more freedom. This trend is clearly visible in the economic policy or reforms that were approved after 1968 (see the next subchapter).

Political relaxing deepened during the time and led even to the forming of an opposition in the middle of the 1980s. Negotiations around the round table took place in 1989, resulting in a change of the constitution that guaranteed transition to democracy, market economy, human rights and explicit ban of a single party government (even in the situation when the party has majority in the parliament). This change was approved on October, 23, 1989, and it is considered to be the beginning of new democratic Hungary. This way, the country "jumped" directly into democracy with free elections in March 1990. Hungarians avoided any form of pseudo-democracy or government of national unity.

\section{Economic Situation and Development Before 1989}

Political development had an immediate impact on the development of the Hungarian economy. The centrally planned system had been established in the country after the Second World War. There were of course differences to other centrally planned systems in the region but the basis of the system was similar. The Hungarian system was generally never as tough as in Czechoslovakia but even bigger differences started to appear as they introduced reforms after 1968.

The core of the reforms (named New Economic Mechanism) consisted in decentralization of the decision-making process in the economy that was shifted from the centre to the companies. But the main decisions (for example about investment or armament industry) were still made by the government. On the other hand, companies were relatively independent - in contrast to their counterparts in Czechoslovakia.

The central government regulated prices, wages and interest rates but in the course of time, more responsibility was shifted to companies. And there were many more striking differences. In the 1980s, foreign direct investment was allowed and joint-ventures with western companies appeared. As early as 1989, Hungary lured the first car producer Suzuki, and Tunsgram was purchased by GE Lighting Europe.

Hungary unified its exchange rate in 1981 already. $^{2}$ And following 1988, all enterprises were allowed to pursue international trade in convertible currencies after gaining a (virtually automatic) registration with the Ministry of Trade (Medvec, Stone, 1990). Hungary became a member of the IMF already in 1982. The country agreed on a standby program as early as 1988 - in comparison, Czechoslovakia did not become a member of the organization during the communist period at all.

\footnotetext{
${ }^{2}$ Multiple exchange rates were common in centrally planned economies. They created distortion and malfunctioning of the system. Unifying exchange rate was a step in the direction towards an ordinary economic system.
} 
Hungary passed a bankruptcy law in 1986 (even though it was not used). A two-tier banking system was introduced in 1987 - the previous monobank split into the central bank and 3 commercial banks. The economy started to open that year, too; in 1990, 70\% of their production had already been under pressure of foreign competition (Stojanov, 2004). Hungarian companies were allowed to trade internationally on their own accounts.

A new commercial code was approved in 1988. The main legal forms were the same as in the market economy - and all of the legal forms were equal. The government started to transform state companies into joint-stock companies in 1989.

Hungary was the first country of Central Europe to have incorporated value added tax into the tax system, which occurred in 1988. Furthermore $63 \%$ of all prices were liberalized already in $1989 .^{3}$ There were continuous devaluations of the forint - from 45.8 to USD in 1986 to 63.2 in 1990 (Vintrová, 1992).

Ownership structure changed as well. Some private companies (especially in services and trade) were allowed to exist and their numbers increased steadily, which can be seen in the following table. There was even support for new private entrepreneurs. According to a new act of 1988, newly created businesses got a discount on tax on profit accounting to $55 \%$ in the first year, $35 \%$ in the second year, and $25 \%$ in the third year (Earle at al., 1994).

Table 1: Number of Private Shops and Restaurants in Hungary

\begin{tabular}{c|cc}
\hline Year & Shops & Restaurants \\
\hline 1970 & 9,043 & 682 \\
1980 & 9,946 & 1,457 \\
1985 & 19,968 & 5,487 \\
\multicolumn{2}{|c}{ Source: Bethkenhagen, Hungary in GDR and Eastern Europe, 1989}
\end{tabular}

Bethkenhagen (1989) wrote that private sector had created $3 \%$ of national product in 1970. In 1989 it created already more than one quarter (Holman, 2000) and two thirds of Hungarians had an income from private activity in addition to their main jobs in a state company or a cooperative. These numbers are several times higher compared to Czechoslovakia's numbers but are of course far from any market economy.

The previous text shows that Hungarian economy was ahead of the others and to a certain degree prepared for the shift to the market economy. But at the same time, there were significant problems on the macro-economic level, too: The country had huge deficits of the public finance and trade. Both of them can be connected to the "goulash socialism" because government had to "bribe" its citizens. Together, these deficits were responsible for a large foreign debt $-70 \%$ of GDP (Markiewicz, 2003). This size of the deficit was crucial for the following transformation steps. But this number was still

\footnotetext{
${ }^{3}$ EBRD has a basket of 15 basic consumption goods. The statistics says that in 1989 , only prices of 7 out of the 15 goods were administrated by the government. The corresponding number for Poland was 10, and for the Czech Republic 15 (EBRD, 26. 11. 2007).
} 
lower than in Poland. Another way of measuring external debt can be seen in the following table.

Table 2: External Debt/Exports of Goods and Services in \%

\begin{tabular}{l|cccccc}
\hline & 1985 & 1986 & 1987 & 1988 & 1989 & 1990 \\
\hline Czechoslovakia & 32.4 & 33.8 & 36.2 & 40.2 & 45.1 & 56.3 \\
Hungary & 148.5 & 166 & 174.9 & 173.8 & 169.7 & 171.7 \\
Poland & 252.1 & 259.5 & 294.8 & 254. & 261.7 & 251.5 \\
\hline
\end{tabular}

Source: Jonáš, Ekonomická transformace v České republice, 1997

The role of the government in the form of redistribution used to be very high in Hungary during the communist period - or in fact one of the highest even among the centrally planned economies - see the next table.

Table 3: Government Incomes and Expenditures in \% of GDP in 1989

\begin{tabular}{l|cc}
\hline Country & Incomes & Expenditure \\
\hline Czechoslovakia & 62.1 & 64.5 \\
Hungary & 61.3 & 63.7 \\
Poland & 46.8 & 48.7 \\
Rumania & 45.7 & 40.7 \\
Bulgaria & 57.7 & 60.1 \\
Soviet Union & 43.8 & 50.7 \\
USA & 34.3 & 36.5 \\
Germany & 45.7 & 45.9 \\
Canada & 40.3 & 43.9 \\
France & 46.2 & 47.8 \\
\hline
\end{tabular}

Source: Jonáš, Ekonomická transformace v České republice, 1997

Table 4: Structure of Employment in 1990 (Shares in \%)

\begin{tabular}{l|ccc}
\hline & ČSSR & Hungary & Poland (1989) \\
\hline Agriculture & 11.8 & 17.5 & 26.7 \\
Industry & 45.4 & 36.1 & 36.6 \\
Services & 42.8 & 46.4 & 36.7 \\
\hline \multicolumn{2}{l}{ Source: Berend, From the Soviet Bloc to the European Union, 2009}
\end{tabular}

The structure of the economy was troublesome, too. In the following table we can notice a relatively high percentage of people still working in agriculture. On the other hand, Hungary had a relatively low share of industry, which was assumed to be the most problematic part of the economy in the transformation process. And it meant relatively 
lover ecological burden, too. At the same time, Hungary had the highest proportion of people working in services in Central Europe.

How the reforms and changes during the communist reign reflected in the economy? As we can see in the following figure, the overall trend in Hungary was similar to other countries of the Eastern Block after the Second World War, but the growth was affected by more significant fluctuations than in Czechoslovakia. The economy was able to achieve strong growth during the 1950s but this ability declined in the following decades to very low growth during the 1980 s (the average was only $0.7 \%$ per a year Maddison, 2010). The general trend is clearly visible in the following figure. Economic reforms generally did not lead to improvement in the trend of economic growth. On the contrary, economic results were worsening.

Figure 1: Economic Growth During the Communist Regime (1948-1989) and its Trend Estimated with HP Filter

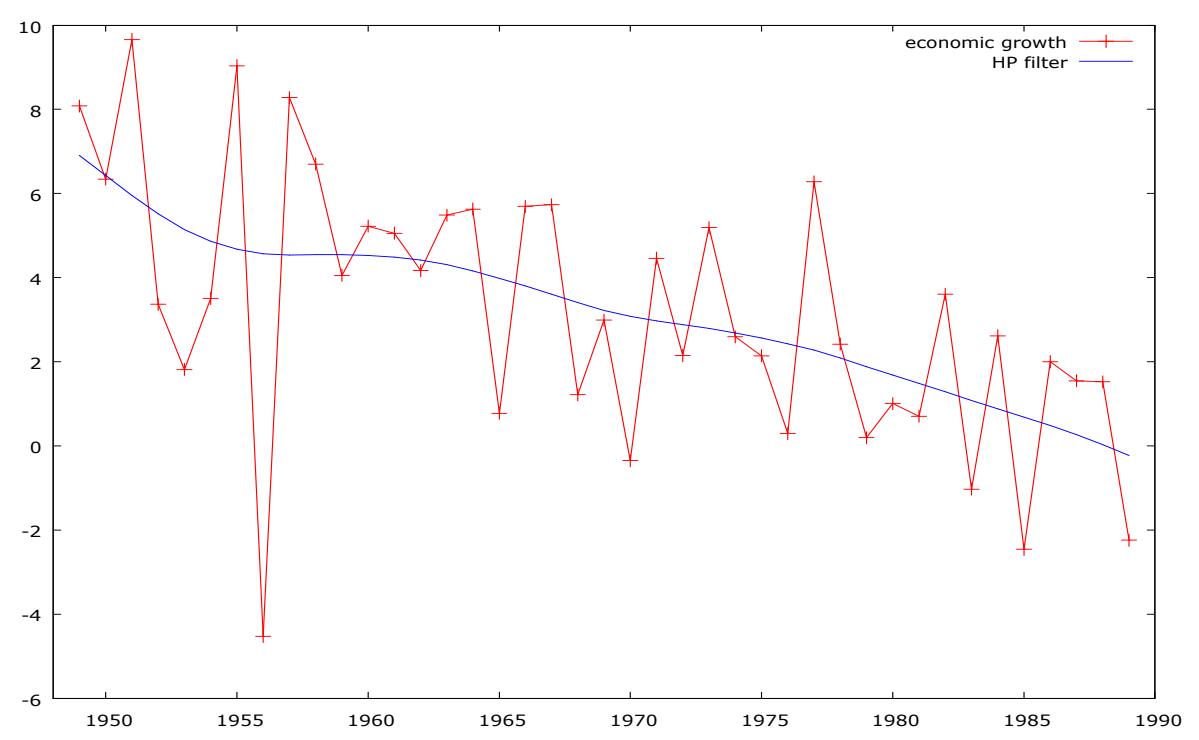

Source: Maddison, Historical Statistics - http://www.ggdc.net/MADDISON/oriindex.htm (11.10.2010)

In the 1980s inflation was relatively high as well (see Figure 9) - on average it achieved 9\% (IMF, 9. 10. 2010), which was much higher in comparison to Czechoslovakia, but a good result when compared to Poland. Hungary had a high level of debts and deficit of trade balance. And there was even a small number (12 000) of unemployed people in $1989-0.5 \%$ of the labor force (EBRD, 26. 11. 2007).

Summing up the previous information, we could say that Hungary was relatively well prepared for the transformation at the level of formal institutions and at the microeconomic level. However, it faced problems at the macroeconomic level: a relative openness of the society resulted in a relatively higher proportion of people/economists with knowledge about functioning of the market economy. Some Hungarians even suffered a kind of "hubris" at the end of the 1980 s that was caused by 
the progress of the reforms. They thought that the transformation process will be smooth because of the steps that had been already taken in the decade. This attitude led to a belief that radical steps were not necessary and it lasted well into the 1990s when people finally realized that unpopular steps were necessary to take (Srholec, 2001).

General comparison of the situation at the beginning of the 1990s can be seen in the following table.

Table 5: Basic Economic Indicators at the Beginning of the 1990s*

\begin{tabular}{l|ccc}
\hline & CR & HUN & POL \\
\hline Inhabitants in millions & 10.36 & 10.36 & 38.11 \\
Economic activity in \% & 51.6 & 52 & 42.7 \\
Employment in industry \% of total & 37.9 & 29.7 & 28.4 \\
Investment in \% & 37.9 & 29.7 & 28.4 \\
GDP in billions \$ PPP & 98.97 & 59.6 & 160.86 \\
GDP/person \$ PPP & 9,550 & 5,750 & 4,221 \\
EX per person in \$ & 873 & 922 & 376 \\
IM per person in \$ & 945 & 832 & 250 \\
Gross external debt per person & 686 & 2,077 & 1,270 \\
In \% of GDP & 21.9 & 65.1 & 82.2 \\
\hline *-1990 or the closest year
\end{tabular}

Source: Chvojka, Zeman, Tendence dosavadního vývoje zemí střední a východní Evropy, 2000

We described political and economic situation in Hungary at the end of the 1980s. It creates a starting point for our analyses of the whole transformation process. Before we turn our attention towards the economy, we shortly describe political development during the period, which creates a framework for the development of the economy.

\section{Political Development}

We have already mentioned that the first free elections took place in March/April of 1990. The first post-communist government was created by Jozsef Antall (1932-1993). The government was central-right and based on Christian and national parties. It had a strong majority of $60 \%$ in the parliament, which gave the government a stable position. One of its achievements was that Soviet troops left Hungary in the middle of 1991. In the same year, the association agreement with the European Community was signed as well.

There was a great discussion about the role of the previous communist elites after the political changes in all of the post-communist countries. In Hungary, the Communist Party transformed itself into the Hungarian Socialist party (MSZP) - a standard left wing (social democratic) party after 1989. But there is an interesting question of the specific role of the nomenclature after the political change. A survey was executed among these previous elites in 1993 and its result can be seen in the following table. We 
should notice that only a fraction of the previous nomenclature members occupied high political positions. At the same time, only a very small percentage of them became entrepreneurs, which is true about all Central European countries.

Table 6: Occupational Destinations in 1993 of People Who Were in the Nomenclature Positions in 1988 by Country

\begin{tabular}{l|ccc}
\hline Occupation in 1993 & Czech Republic & Hungary & Poland \\
\hline All in position of authority & 51.7 & 43.1 & 51.2 \\
High political office & 3.0 & 6.4 & 9.0 \\
High manager-public & 16.2 & 11.2 & 13.4 \\
High manager-private & 12.8 & 2.4 & 9.1 \\
High cultural office & 1.1 & 4.4 & 7.1 \\
Low-level managers & 12.6 & 13.0 & 8.6 \\
Entrepreneurs & 6.0 & 5.7 & 4.0 \\
Professionals & 12.2 & 19.9 & 13.9 \\
Workers & 12.6 & 5.5 & 9.5 \\
Retired early (younger than 65) & 15.4 & 19.1 & 17.2 \\
Other retired and unemployed & 8.1 & 12.6 & 8.2 \\
All respondents & $100 \%$ & $100 \%$ & $100 \%$ \\
(number) & $(468)$ & $(803)$ & $(849)$ \\
\hline
\end{tabular}

Source: Eyal, Szelényi, Townsley: Making Capitalism Without Capitalist: Class Formation and Elite Struggles in Post-Communist Central Europe, London Verso, 1998

The MSZP post-communist left wing party won the next elections in 1994 by landslide. Due to the economic situation they were forced to introduce tough economic measures (of which more later). A right wing coalition government (Fidesz was the main party) was created after the elections in 1998. Hungary joined NATO during its regime. Fidesz won the next elections in 2002 as well but was not able to assemble a government that was formed by left wing parties instead.

Generally, the country adhered to democratic principles for the whole period and became a member of the European Union in 2004. But there has been a lasting dissatisfaction with the transformation process and life in general in Hungary. The results of one of the surveys (2006) are depicted in the following table. ${ }^{4}$ Personally, I do not have any reasonable explanation for this attitude. We can consider high expectations of the Hungarians at the end of the 1980s and a possibility that they were generally content with the semi-capitalist system of the goulash communism.

\footnotetext{
${ }^{4}$ There are other (older) surveys that detect the same attitude among Hungarians. The conclusion is that their view was not affected by the financial crisis.
} 
Table 7: Results of the Survey - A Comparison of Economic Situation in 2008 and 1991 (Q: Thinking back to 1989/1991, do you approve of your country moving from having a state controlled economy to having a market economy?)

\begin{tabular}{|c|c|c|c|c|c|c|c|c|}
\hline & & & 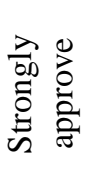 & $\begin{array}{l}0 \\
0 \\
\frac{0}{2} \\
\frac{2}{2}\end{array}$ & 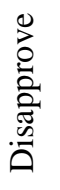 & 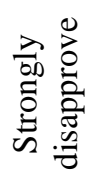 & 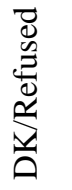 & تేّ \\
\hline \multirow[t]{2}{*}{ Poland } & Fall & 2009 & 26 & 45 & 11 & 4 & 13 & 100 \\
\hline & Spring & 1991 & 25 & 55 & 7 & 4 & 9 & 100 \\
\hline \multirow[t]{2}{*}{ Czech Rep. } & Fall & 2009 & 28 & 51 & 12 & 3 & 5 & 100 \\
\hline & Spring & 1991 & 42 & 45 & 4 & 3 & 6 & 100 \\
\hline \multirow[t]{2}{*}{ Hungary } & Fall & 2009 & 9 & 37 & 27 & 15 & 13 & 100 \\
\hline & Spring & 1991 & 22 & 58 & 9 & 1 & 10 & 100 \\
\hline
\end{tabular}

Source: The PEW: Global Attitudes project, www.pewglobal.org, published 2. 11. 2009, 15. 5. 2013

After this short summary of the political development we can turn our attention towards economic aspects of the transition process. First of all, we will briefly sum up a discussion about the pace of reforms.

\section{Basis of economic transformation}

The sequence of the reforms in Hungary was under similar discussion as in other countries at the beginning of the transformation period. Hungary was specific in the fact that its communist party had started reforms before the fall of the regime already. Hungarians therefore naturally believed that it was not necessary (or it was de facto impossible) to follow radical reforms. There was a general belief that slower reforms can bring the same results with lower costs. On the other hand, proponents of a shock therapy did not trust government ability to establish market economy. As a consequence, the first period of Hungarian transformation is often described as gradualist but there are always troubles with the definition of gradualism. Some of the Hungarian measures especially bankruptcy law - can be seen as extremely radical. The second subchapter deals with reforms which took place in the middle of the 1990s, and the last, third subchapter concentrates on the period after the turn of the century.

\section{Gradualist period}

Most authors (for example Holman, 2000, or Lavigne, 1999) regard the development in the first half of the 1990s in Hungary as gradualism. There is a good basis for this view - as we wrote above - since many of the important and necessary steps in the direction towards the market had been already taken or at least prepared. We have already mentioned liberalization of prices - in 1991, when $90 \%$ of all prices had already been liberalized (Vintrová, 1992). The economy was partly deregulated as well; Hungary did not have a huge surplus of money in circulation and their exchange rate was relatively sound (Vintrová, 1992). We should keep in mind the progress in institutional 
development as well. ${ }^{5}$ Under these circumstances it is hardly imaginable to carry out a real radical economic transformation, let alone the shock therapy. At the same time, we should mention that there was no demand for a fast or radical change. ${ }^{6}$

We have already mentioned that Hungarian economy had suffered from macroeconomic imbalances. Laki (1993) wrote that the Antall government had had three main tasks - to keep creditworthiness of the country, reduce inflation and the growing public deficit. The last of these tasks was the most demanding one because after the communist regime had collapsed, problems with public finance worsened. With the fall of the regime the state income declined but the cabinet was not able to simultaneously decrease its expenditures. On the contrary, the government quite often took on responsibilities for late state companies that had provided social services to the public and it led to another increase in spending (Allen, Hass, 2001).

Borish and Noël (1996) wrote that state owned companies had been losing money and their gross loss had reached $2.6 \%$ of GDP in $1990,8.4 \%$ in $1991,14.2 \%$ in $1993,10.1 \%$ in 1993 , and $7.5 \%$ in 1994. The IMF recommended that Hungarian government decrease deficits but the cabinet was not capable of meeting these expectations. A part of this deficit was even monetized, as we can see in the following table.

Table 8: Overall Government Balances and Central-bank Financing of Governments, 1992-1997 (As a Percent of GDP)

\begin{tabular}{|c|c|c|c|c|c|c|c|c|c|c|c|c|}
\hline \multirow[t]{2}{*}{ Country } & \multicolumn{6}{|c|}{ Overall government balances } & \multicolumn{6}{|c|}{ Central-bank financing } \\
\hline & ๙ু & $\stackrel{\Omega}{\Omega}$ & ১ু & $\stackrel{n}{2}$ & ஓ & ลิ & ふૂ & ڤ̊ & ஓ̆ & $\stackrel{2}{2}$ & ஓे & 亏ิ \\
\hline Czech R. & $\ldots$ & $\ldots$ & -1.2 & -1.8 & -1.2 & -2.1 & $\ldots$ & -2.1 & -2.4 & -1.0 & -0.8 & 0.7 \\
\hline Hungary & -6.9 & -8.5 & -8.3 & -7.1 & -3.1 & -4.6 & 16.5 & 13.2 & 11.2 & 7.5 & 7.3 & 1.7 \\
\hline Poland & -7.5 & -4.0 & -2.0 & -2.7 & -2.5 & -2.3 & 5.2 & 1.5 & 1.5 & 0.1 & 0.1 & 0.5 \\
\hline
\end{tabular}

The government was unwilling to execute unpopular steps - like decline in real wages or devaluation (on the contrary to Czechoslovakia and Poland) - either. ${ }^{7}$ Holman (2000) writes that real wages in all countries declined at least by $20 \%$ (for example in Bulgaria by $50 \%$ ), but Hungary was an exception - see the following table. It means at the same time that wage costs remained relatively high in comparison to other Central European countries, which resulted in growing imbalances. The IMF criticized the government for

\footnotetext{
${ }^{5}$ Overall Hungarian progress has been supported by foreign funds in the form of Poland and Hungary Aid for Economic Restructuring (PHARE) since the autumn of 1989.

${ }^{6}$ In Hungary, a new constitution (unlike in all neighbouring countries) was not ratified until 2011, there were only amendments.

${ }^{7}$ In order to keep the real exchange rate roughly stable, Hungary has followed a path of irregular devaluations of the exchange rate since 1990 . The currency was devaluated three times in 1990 but together only by 5\%; twice in 1991 (together 21\%); three times in 1992 (together 6\%); five times during 1993 (together 15\%) and seven times during 1994 (together 17\%) (Magyar Nemzeti Bank, http://english.mnb.hu/Root/ENMNB/Statisztika, 20. 10. 2010).
} 
not keeping fiscal promises in 1992 when the country significantly exceeded the agreed ceiling, mainly due to social requirements.

Table 9: Real Wages: Annually in Percentage Change

\begin{tabular}{l|cccc}
\hline & 1988 & 1989 & 1990 & 1991 \\
\hline Czechoslovakia & 2.1 & 0.8 & -5.8 & $-23.5^{*}$ \\
Hungary & & -4.3 & -3.8 & $-7.5^{* *}$ \\
Poland & 15.9 & -4.4 & -29.7 & $2.0^{* *}$ \\
\hline * - Jan - Sept 1991; ** - preliminary \\
Source: Winiecki; Regional Survey, 1993
\end{tabular}

However, Hungarian government proceeded with reforms of the business and the financial sectors at the same time. Steps were taken to improve the legal system, to privatize, to improve antitrust policy, and foremost in the field of bankruptcy. Hungarian gradualism is highly questionable if we take into account the bankruptcy legislation. A very tough new code was in effect from the beginning of 1992. If a company was not capable of paying its debts within 90 days, it had to call to start bankruptcy proceeding itself. The law was in force for 18 months, and 5,000 subjects went bankrupt (Holman, 2000). These subjects together had created 10\% of Hungarian GDP (Nestor, Thomas, 1995). This bankruptcy proceeding was in fact a privatization method at the same time because around 500 large companies that had gone bankrupt were transferred into private ownership (Nestor, Thomas, 1995). The process had a negative impact on the banks that were affected by the growing number of classified credits. We should recall that in comparison to that, bankruptcy legislation was very weak in the Czech Republic - in the same period considered, the very first law was approved in 1993 only and it could not been applied against companies waiting to be privatized. Politicians in Hungary realized that their code was probably too tough and it was amended in 1993. This amendment meant relaxing and resulted in less than 100 companies going bankrupt in 1995 (Srholec, 2001). The same author thinks that the process cleaned the economic environment and improved the position of Hungarian banks in the long run.

To sum up, we can see progress on the microeconomic level and unsolved problems on the macroeconomic level as a consequence. Czechoslovak reformers, on the other hand, kept the macroeconomic values relatively stable in the first years of transformation but bankruptcies were for example limited.

The economic results in Hungary in this period were not positive. If the country represents a case of a gradual reform, then gradualism turned out incapable of avoiding transformation recession. Hungary suffered similar (or deeper) decline as other countries in Central Europe. Unemployment rate was relatively high. Inflation development did not embrace the typical jump after the price liberalization (that took place in other countries) but there was a continuously higher inflation rate. On the positive side, a relatively high level of foreign capital was flowing into the country. It had again its roots in the previous liberalization because foreign investors were familiar with situation in Hungary. At the same time, deficit of the current account appeared. 


\section{The Bokros Package}

In 1994, Hungarian economy faced a difficult situation with many imbalances, as we can see in the following table. Government deficit reached $8.4 \%$ of GDP, public debt was $88 \%$ of GDP, the deficit of the current account stood at $9.5 \%$ GDP, inflation was $18.8 \%$ and the unemployment rate nearly $11 \%$. The level of imbalances was critical Holman (2000) writes that the IMF placed Hungary among three most vulnerable economies in the world after the Mexico crisis. As a consequence, the spread on external debt to Libor rate reached 500 basilar points (Stojanov, 2004).

Table 10: Selected Economic Indicators for Hungary, 1993-1998

\begin{tabular}{|c|c|c|c|c|c|c|}
\hline & 1993 & 1994 & 1995 & 1996 & 1997 & 1998 \\
\hline \multicolumn{7}{|l|}{ Real sector: $\%$ change } \\
\hline Real GDP & -0.6 & 2.9 & 1.5 & 1.3 & 4.6 & 5.1 \\
\hline Exports of goods/services (real) & -10.1 & 13.7 & 13.4 & 7.4 & 26.4 & 16.3 \\
\hline Imports of goods/services (real) & 20.2 & 8.8 & -0.7 & 5.7 & 25.5 & 22.5 \\
\hline Fixed investment (real) & 2 & 12.5 & -4.3 & 6.7 & 9.2 & 11.4 \\
\hline Private consumption (real) & 1.9 & -0.2 & -7.1 & -2.7 & 1.7 & 3.8 \\
\hline Average CPI & 22.5 & 18.8 & 28.2 & 23.6 & 18.3 & 14.3 \\
\hline Gross wage growth (real) & -0.5 & 5.1 & -8.9 & -2.6 & 3.4 & 4.4 \\
\hline $\begin{array}{l}\text { Real effective exchange rate } \\
\text { (unit labor cost) }\end{array}$ & 4.3 & 7.3 & 19.4 & 8.6 & 2.7 & 8.5 \\
\hline Unemployment rate (end period) & 12.6 & 10.9 & 10.9 & 10.7 & 10.4 & 9.1 \\
\hline \multicolumn{7}{|l|}{ Real sector: $\%$ of GDP } \\
\hline Exports of goods and services & 26.4 & 28.9 & 37.3 & 38.9 & 45.5 & 49.8 \\
\hline Imports of goods and services & 34.6 & 35.4 & 38.5 & 39.9 & 46 & 52.3 \\
\hline Fixed investment & 18.9 & 20.1 & 20 & 21.4 & 22.1 & 23.2 \\
\hline \multicolumn{7}{|l|}{ General government } \\
\hline $\begin{array}{l}\text { Overall balance (excl. } \\
\text { privatization) }\end{array}$ & -6.6 & -8.4 & -6.4 & -3 & -4.8 & -4.7 \\
\hline $\begin{array}{l}\text { Overall balance (incl. } \\
\text { privatization) }\end{array}$ & -6 & -7.5 & -3.2 & 0.8 & -1.8 & -4.4 \\
\hline $\begin{array}{l}\text { Primary balance (excl. } \\
\text { privatization) }\end{array}$ & -2.7 & -2.2 & 2.2 & 3.7 & 2.7 & 1.6 \\
\hline Expenditures & 60.8 & 60.4 & 54.3 & 49 & 49.2 & 47.1 \\
\hline Public debt & 90.4 & 88.2 & 86.4 & 72.8 & 63.9 & 60.2 \\
\hline \multicolumn{7}{|l|}{ External accounts } \\
\hline Trade balance & -8.4 & -8.8 & -5.5 & -5.9 & -3.8 & -4.4 \\
\hline Current-account balance & -9 & -9.5 & -5.3 & -3.7 & -2.1 & -4.8 \\
\hline Foreign direct investment & 6 & 2.8 & 10 & 4.4 & 3.6 & 3 \\
\hline Gross external debt & 63.7 & 68.4 & 70.9 & 61 & 51.9 & 56.3 \\
\hline Net external debt & 38.7 & 45.4 & 36.6 & 31.4 & 24.4 & 26 \\
\hline
\end{tabular}

Source: Stojanov, Hungary and Bosnia and Herzegovina: A Success and a Failure of Transition, 2004

The elections took place in 1995. Social democrats, the winners, agreed to apply a program that is often called the Bokros package according to the then ministry of finance Lajos Bokros (1954-). The set of reforms had been developed in cooperation with the IMF. The government promised to follow steps in the direction to austerity and 
the IMF in exchange provided the country with a loan of USD 300 million and the EBRD released its funds as well (Hanley, King, János, 2002).

The package involved many other remedies, too. The exchange rate was devaluated by $9 \%$ and the regime changed to crawling peg. ${ }^{8}$ At the same time, the government introduced temporary import surcharge $-8 \%$ on all (non-investment) goods, ${ }^{9}$ and applied many restrictive measures as well: It decreased the number of jobs in state companies; university tuitions were introduced; rules for sick benefits were tightened and child benefits were not blanket any more. Agreements on real wages reduction were reached with most trade unions. At the same time, the government decided to quickly privatize nearly all state companies bar railways and the post - mostly in the form of foreign direct investment, as we can see in the following table.

Table 11: FDI Inflows in Hungary in USD mil (1972-2000)

\begin{tabular}{c|ccccc}
\hline & In cash & $\begin{array}{c}\text { Of which } \\
\text { privatization } \\
\text { income }\end{array}$ & as\% & $\begin{array}{c}\text { Investment in } \\
\text { kind }\end{array}$ & Total \\
\hline $1972-1989$ & 387 & - & 6.4 & 589 & 1170 \\
1990 & 311 & 20 & 29.8 & 155 & 900 \\
1991 & 1459 & 435 & 33.4 & 170 & 1614 \\
1992 & 1471 & 492 & 49.7 & 142 & 1641 \\
1993 & 2,339 & 1,163 & 9.0 & 173 & 2,481 \\
1994 & 1,147 & 103 & 75.7 & 185 & 1,320 \\
1995 & 4,453 & 3,370 & 31.2 & 57 & 4,638 \\
1996 & 1,983 & 618 & 87.6 & 22 & 2,040 \\
1997 & 2,085 & 1,827 & 25.1 & 11 & 2,107 \\
1998 & 1,935 & 485 & 17.9 & 6 & 1,946 \\
1999 & 1,651 & 295 & 0.0 & $0 *$ & 1,657 \\
2000 & 1,600 & 0 & 43.1 & 1510 & 1,600 \\
$1990-2000$ & 20,434 & 8,808 & & 21,876 \\
\hline
\end{tabular}

*- in the fiscal year 2000, this figure was equal to USD 280.00 - which is 0 while rounded to millions

Source: Csáki, From Transition to Integration, 2002, own calculations

Holman (2000) adds that these general restrictive measures were similar to Czechoslovak steps at the beginning of the transformation process, and it seems that they are unavoidable in the transformation process. We should remark that some of the

\footnotetext{
${ }^{8}$ The crawling peg system is based on small devaluations of the currency on the regular (usually monthly) basis. First of all, the central bank decided on devaluation of $1.9 \%$ per month as of spring of 1995 . The rate of devaluation declined in the following years to $0.6 \%$ per month from January 1, 1999, 0.3\% from January 1, 2000, and finally 0.2\% from April 1, 2001 (Magyar Nemzeti Bank, http://english.mnb.hu/Root/ENMNB/Statisztika, 20. 10. 2010).

${ }^{9}$ Import surcharge was consequently gradually removed in accordance with the plan (Tomšík, 1998).
} 
measures were revoked or weakened by the Parliament or the constitutional court in the following years.

The goal of these steps was obvious. The government wanted to reduce deficits of the public finance and the trade balance and increase competition in the economy. The consequences of the measures were harsh - government expenditure declined by $10 \%$ of GDP (Stojanov, 2004); real wages decreased by 12\% in 1995 and 4\% in 1996 (Holman, 2000), and economic growth slowed down to just $1 \%$ in both 1995 and 1996. At the same time, the main imbalances in the economy narrowed - the trade deficit declined between 1994 and 1996. The government deficit (without incomes from privatization) diminished from $8.4 \%$ to $3 \%$ in the same period as well (see the previous table). Overall development of public finance during the first decade can be seen in the following figure. We can see that average deficit was relatively high - between 1990 and $20045.5 \%$ of GDP (EBRD, 26. 11. 2007). These results were generally the worst from the CentralEuropean countries.

\section{Figure 2: Deficit in Public Finance in \% GDP}

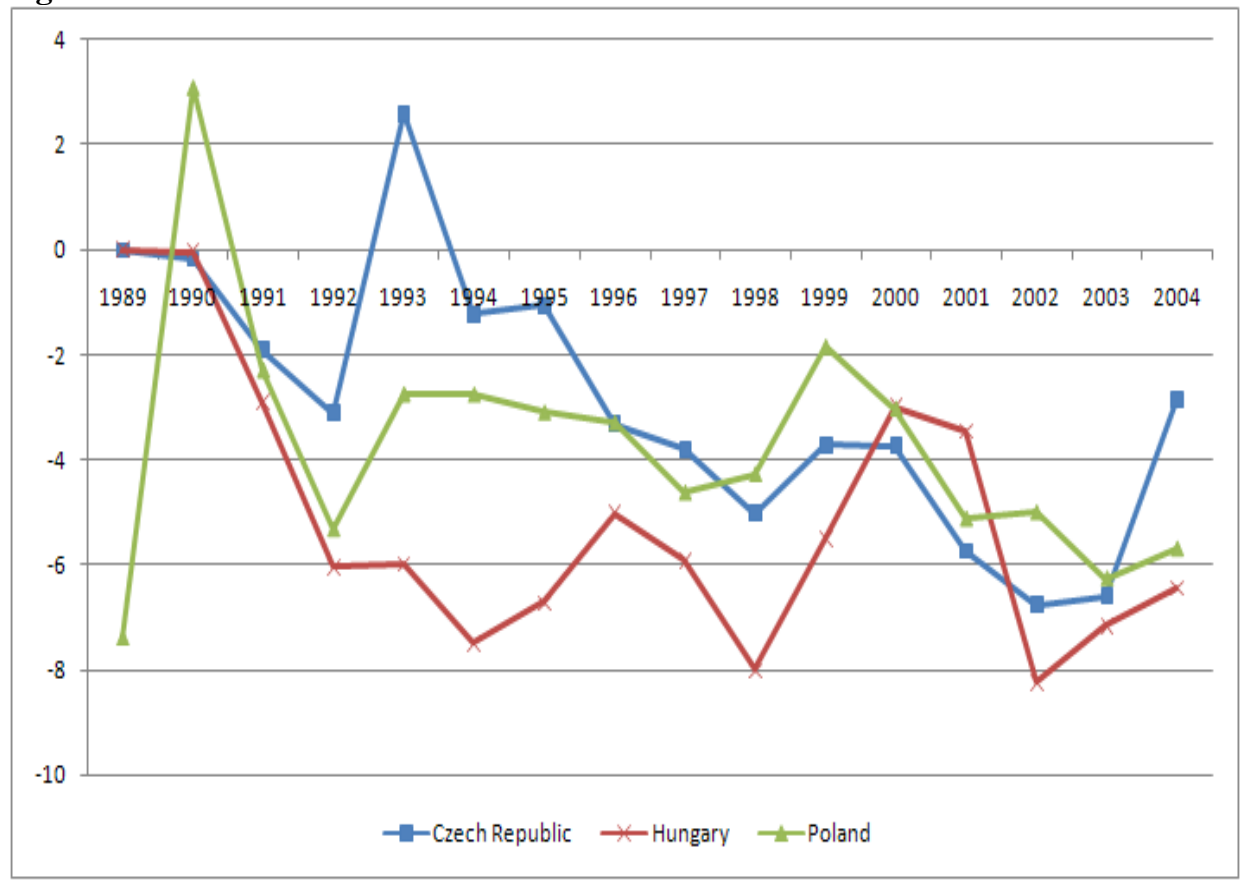

Source: EBRD: Selected economic indicators data, 26. 11. 2007.

We can offer another conclusion resulting from the crisis. We should notice that Hungary dealt with the problems with outer balance by admitting devaluation and inflation. In comparison to that, Czech exchange rate soon returned to the nearly precrisis level after the Czech currency crisis had ceased, and inflation declined, too. Foreign investors did not evaluate the development in Hungary as negative, and were willing to invest capital in the country. 
We should mention that changes in the banking sector were connected with the Bokros package, too. Until the mid 1990s, foreign institutions had been banned from keeping more than $25 \%$ in a Hungarian bank without a special permission. This rule was abandoned after 1995 and all large Hungarians banks ended up privatized in hands of European financial institutions by 1997 (Hanley, King, János, 2002). Holman (2000) comments that it was necessary to clean the banking sector before privatization and that it cost around USD 4 billion.

There were changes in the exchange rate policy as well. The overall positive development of the economy and drift to the market economy was appreciated by a membership in the OECD in May of 1996. Some of the authors (for example Gabrisch, Hölscher, 2006) see the period after 1997 as the best of the whole transformation.

\section{Currency Problems at the Beginning of the New Century}

The economic development after applying of the Bokros package is generally deemed to be positive. Unfortunately, this prosperous period lasted only for a few years. And Hungary had to face growing problems at the beginning of the new century. Foremost, Hungarian government created notorious problems in fiscal field, for which government expenditures were to blame. Gabrisch and Hölscher (2006), for example, state that wages in the public sector increased by $12-13 \%$ only in 2002 . Growing deficit of the public finance can be seen in the previous chart. Trade was another source of instability because its deficit was getting larger. The trade deficit reached between 6-8\% of GDP at the beginning of the new century, being partly caused by slowing down of European economies, but mostly by the decline of competitiveness that resulted from growth of wages.

The central bank was worried about lasting inflation pressures and responded by a monetary restriction, widening the fluctuation band from \pm 2.25 to \pm 15 in May 2001 as well. In the summer, the system of inflation targeting was introduced, and the currency became fully convertible. That year in October, crawling peg was abandoned and central parity of the forint was fixed. Generally, the central bank shifted its emphasis from controlling exchange rate to inflation targeting, but the central parity and the fluctuation zone were still valid. It meant that the central bank tried to hit two targets (inflation and exchange rate) by a single tool - interest rates. This task was made even more complicated by free movement of capital. On the other hand, Hungarian authorities decided to fix the currency when inflation was declining and pressures on the nominal exchange rate were expected to be lower.

Shift to the fixed central parity meant a significant change in Hungarian economic policy because the country had followed the strategy of stabilizing the real exchange rate (contrary to the Czech case) during the first decade of the transformation, as we can see in the following figure. In the meantime, Czech currency strongly appreciated in real terms.

After these changes, fiscal policy remained loose and the central bank kept interest rates high. There was appreciation pressure and the exchange rate was above the parity and close to the appreciation side of the bend in the following months. Jonáš (2003) wrote that there appreciation of the currency had been greatly expected, which was fully reflected by speculative pressures in January 2003. A potential change of the central 
parity would have meant possibility to earn money easily. The central bank was in conflict with the government that did not accept the idea of revaluation. Eventually, the bank decided to try to keep the exchange rate in the zone and carried out a massive intervention on the foreign exchange market - the estimation is that the central bank spent EUR 5 billion, or $8 \%$ of Hungarian GDP (Jonáš, 2003).

Figure 3: Nominal (left) and Real Exchange Rate $(1991=100)$ in Hungary, Poland and the Czech Republic 1991-2004

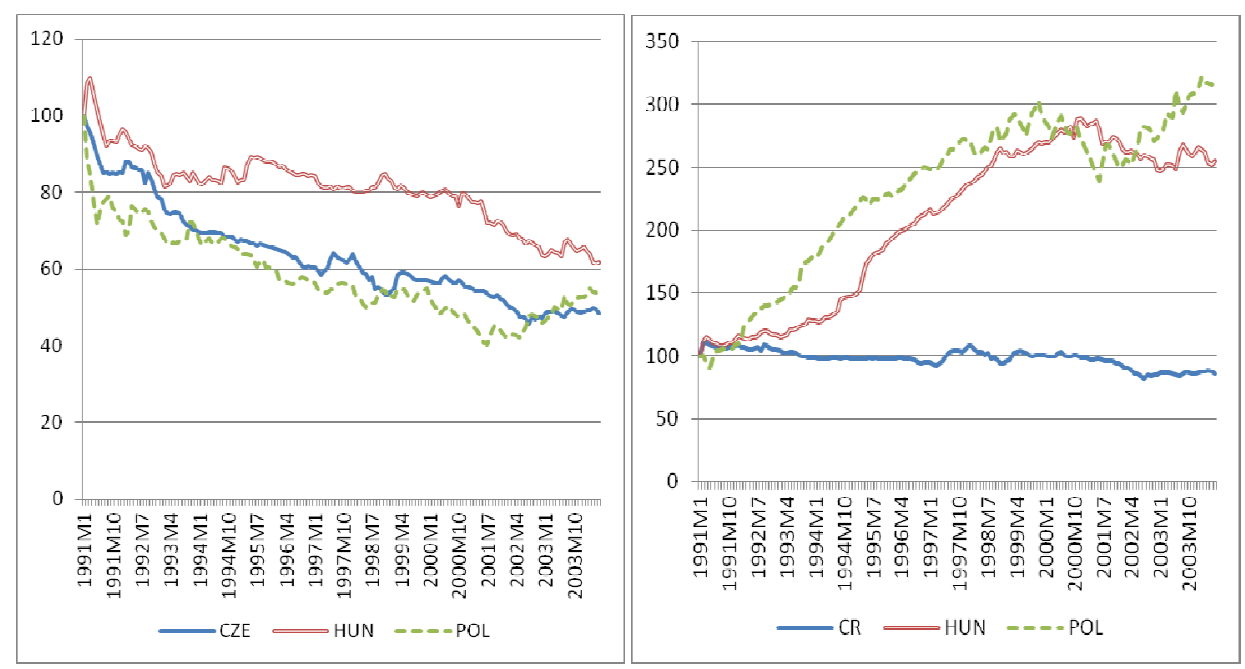

Source: IMF, International financial statistics, http://elibrary-data.imf.org/

These interventions led to increase in money in circulation, and monetary policy was even more relaxed by declining of the interest rates by $2 \%$. These steps resulted in the central bank losing credibility. The government initiated a slight devaluation of the central parity of the forint to euro in June 2003 by $2.26 \%$ to please exporters, but the currency's $\pm 15 \%$ intervention band remained unchanged. This unexpected shift in the exchange rate band caused considerable confusion among investors and resulted in decline of confidence in the currency. The forint took a sharp downward turn (Magyar Nemzeti Bank, 2004). The exchange rate weakened from 245 HUF/euro in April to 266 HUF/euro in June. But the currency still remained within the stronger half of the fluctuation band and returned to its previous values in 2004. However, the situation brought about yet another consequence: Inflation increased and overcame the inflation target, which we can see in the following figure. The whole case seems to be a proof that it is highly difficult to keep inflation and exchange rate targets at the same time. 
Figure 4: Inflation, Its Projection and Inflation Target at the End of 2004

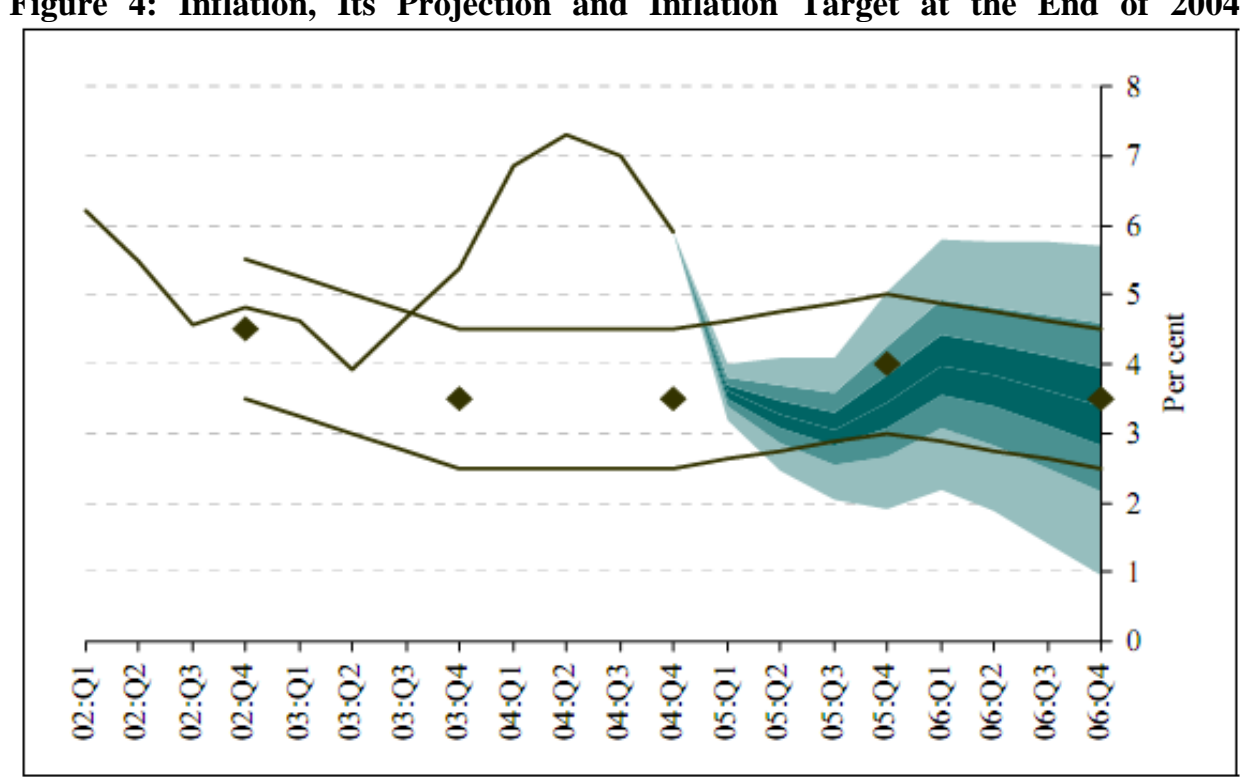

Source: Magyar Nemzeti Bank, Quarterly Report on Inflation, February 2005

These troubles were only minor obstacles on the Hungarian way into the EU. The EU year to year analysis concluded in 2002 that Hungary had passed the Copenhagen criteria - among other things, it meant that the economy was considered a well functioning market economy. The country accessed the EU in 2004.

But the problem with higher inflation that we have mentioned previously caused a negative trend of growing indebtedness in foreign currencies that continued in the following years. This development was important especially for households that often obtained mortgages in Swiss francs or euros. The share and growth of this kind of debt can be seen in the following chart. This development was obviously caused mainly by higher inflation and the fact that interest rates in Hungary were consequently higher than in the developed countries. This dangerous borrowing trend was not creating problems only if the exchange rate was stable or appreciating.

We should notice that high government deficits mentioned above (see Figure 2) were not expressed in growing government debt (in our period) - see the following chart. But both of these negative trends - indebtedness in foreign currencies and growing government debt - caused serious problems to Hungarian economy in the second half of the 2000s. 
Figure 5: Household Indebtedness Over One Year Maturity. Share of Debt in Forints (HUF) and Foreign Currency; and Overall Volume of Debt in Billions of HUF (right scale)

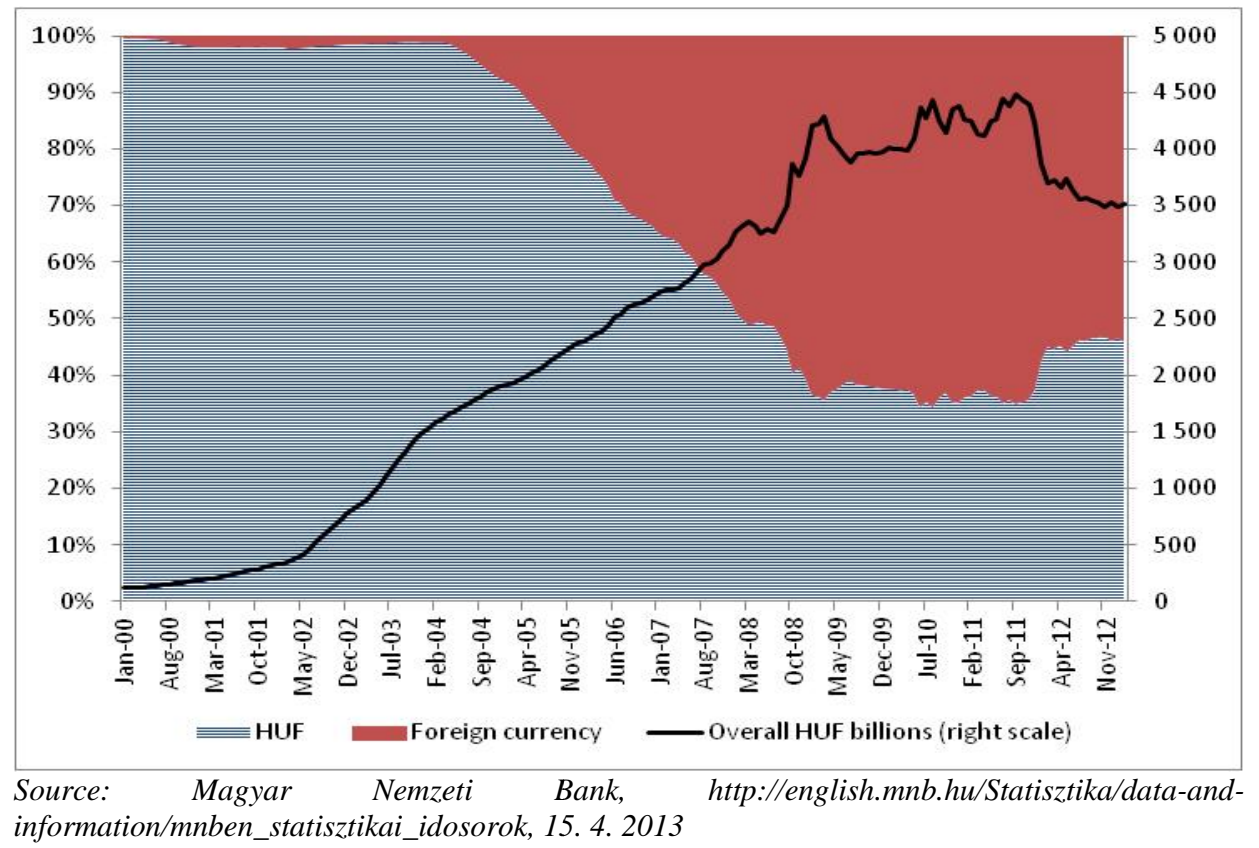

Figure 6: Government Debt as Percent of GDP

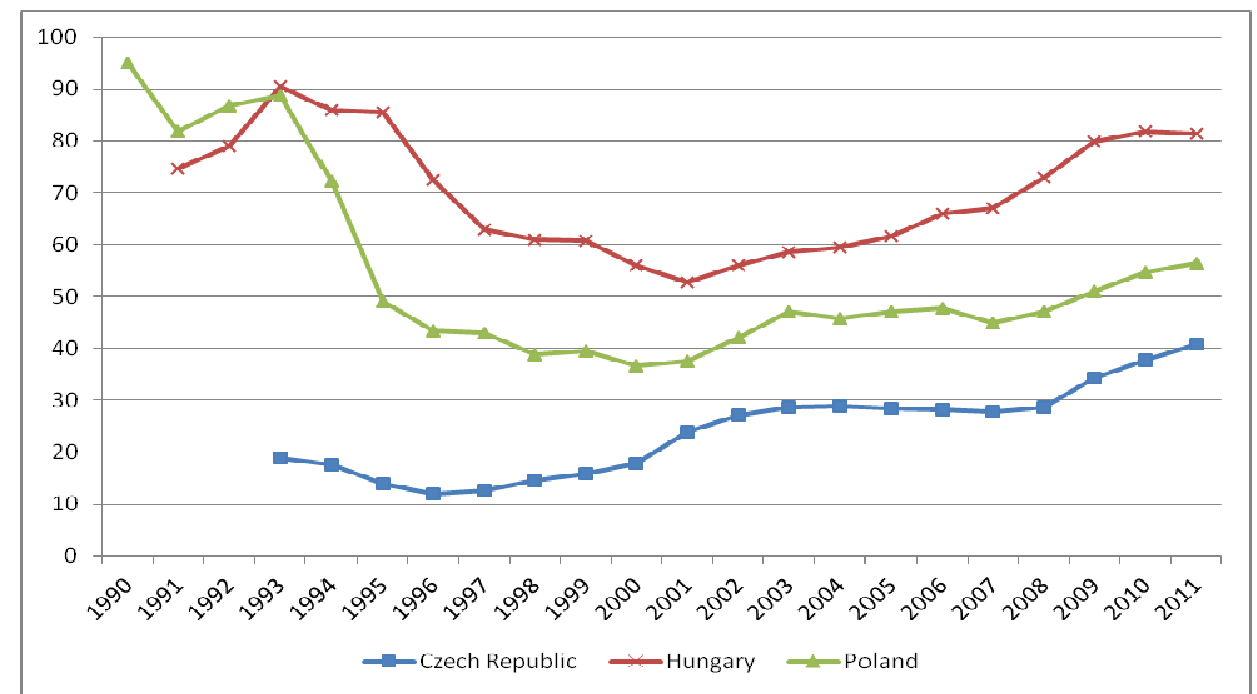

Source: Eurostat ec.europa.eu/eurostat 15. 4. 2013, EBRD Selected economic indicators data, 26. 11.2007 


\section{Privatization}

We have mentioned differences among the central European countries at the beginning of the transformation process. As far as ownership is concerned, the biggest difference was in the role of managers of state companies. In Hungary, their role was much more accepted than in Czechoslovakia, where they were deemed as foremost high-ranking communists. As a consequence, the managers were allowed to gain control over thousands of companies in Hungary already at the end of the 1980s. This process is sometimes called a spontaneous privatization.

As we can see in the following survey, the attitude of the public towards privatization was definitely not unambiguous. The numbers say that restitutions (re-privatization) had low support in Hungary, and that there was relatively high resistance to privatization as such - one of the highest numbers in the whole Eastern Europe. At the same time, however, we can notice the highest support for selling companies for the highest price offered. Laki (1993) wrote that in a survey from middle of $1991,34 \%$ of the respondents were against privatization as such, but as many as $55-60 \%$ were against privatization of their own company. At the same time, there was strong sentiment against foreign investment and return of the previous landowners.

Table 12: Public Survey - How Would you Solve The Problem of Ownership November 1990/August 1991

\begin{tabular}{|c|c|c|c|c|c|c|c|c|c|}
\hline & 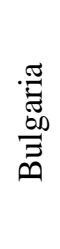 & 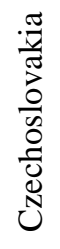 & 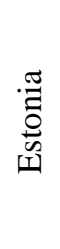 & $\begin{array}{l}\stackrel{己}{\exists} \\
\text { o. } \\
\Xi \\
\Xi\end{array}$ & 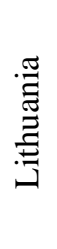 & $\frac{\vec{\Xi}}{\stackrel{\Xi}{0}}$ & 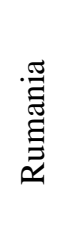 & $\begin{array}{l}\frac{\pi}{\tilde{D}} \\
\frac{0}{\sqrt{0}}\end{array}$ & 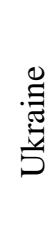 \\
\hline Return to the previous owner & 21 & 34 & 34 & 12 & 14 & 17 & 7 & 20 & 5 \\
\hline Sell for the highest price offered & 15 & 17 & 10 & 29 & 10 & 12 & 19 & 22 & 12 \\
\hline Self-management & 35 & 27 & 39 & 28 & 57 & 47 & 31 & 40 & 53 \\
\hline Keep in state possession & 30 & 22 & 18 & 31 & 19 & 24 & 44 & 18 & 31 \\
\hline
\end{tabular}

Source: Kende, Rovnostářské a etatistické dédictví ve střední a východní Evropě in Politická a ekonomická transformace $v$ zemích střední a východní Evropy, 1993

In comparison to those in Czechoslovakia, some authors consider Hungarian (and Polish) privatizations as decentralized. At the same time, Hungarian (and Polish) privatization at the turn of the decade is often described as "spontaneous" or "wild". The label means that companies were "privatized" into the hands of the management in the first years. Or, seen from a different angle, respective managers was able to gain control over their companies. This development was a result of a high role that management of the companies had played at the end of the communist era. Managements had been gaining independence and autonomy from the 1960s, as we have mentioned. It was a straight contrast to Czechoslovakia where the power had been fully in the hands of the centre until the fall of the regime. Additionally, managements had to compete with other 
potential buyers in Czechoslovak case later on. But we must say that there are probably no estimates of the size of the spontaneous privatization and for example Soós (2011) considers it relatively small.

We have already mentioned the act from 1988 that allowed transformation of the state companies into joint-stock companies in Hungary. This was a turning point that enabled managements to take control over the companies. Insiders kept playing a dominant role in Hungarian privatization at the beginning of the following decade - Earle and Estrin (1996) write that the government was not able to keep full ownership or sell a company to outsiders without insiders consenting of it. The important role of management and their abusing of the power was accompanied by scandals and embezzlement. The public turned against this form of privatization, which resulted in a slowdown of the whole privatization process (Srholec, 2001).

Institutional environment was developed and state Property Fund (SPA) was founded in 1990. This organization became a central agency responsible for privatization. In 1990, SPA controlled 1,975 state companies (1,700 in industry and the rest in agriculture). According to Earle and Estrin (1996) it probably prevented even worse abuse of the situation because the Property Fund had the right to approve of all sales.

The government launched the process of small privatization in the meantime. The first program was called pre-privatization and started in May 1990. It was targeted at retail, and the goal was, among others to stop spontaneous privatization. Roughly 10,000 units were sold or leased between 1991 and 1993. This way of privatization involved mostly small shops and restaurants, which were mainly auctioned. An important factor was that employees of the respective shops gained majority of the property. Changes in property ownership can be seen in the following table.

Table 13: Change in the Affiliation of Units in the Retail and Catering Sector from 1988 to 1992

\begin{tabular}{l|ccc}
\hline Year & 1988 & 1990 & 1992 \\
\hline State enterprises & 26,366 & 17,410 & 14,000 \\
Incorporated companies* & 671 & 6,240 & 30,000 \\
Cooperatives & 27,349 & 22,323 & 18,000 \\
Private entrepreneurs & 34,541 & 60,141 & 102,755 \\
Total & 88,927 & 106,114 & 164,755 \\
\hline
\end{tabular}

*- including limited partnership, limited liability companies, and joint stock companies. They can be private or state-owned

Source: Earle, Frydman, Rapaczynski, Turkewitz, Small privatization, 1994

The large privatization proceeded simultaneously, and its main methods were auctions and tenders; an important role was played by foreign capital, as we can see in the following table. 
Table 14: Privatization Revenues of the State Privatization Companies, 1990-2000, HUF billion

\begin{tabular}{c|cccc}
\hline & $\begin{array}{c}\text { Sales and asset } \\
\text { management }\end{array}$ & Cash revenues & $\begin{array}{c}\text { Of which hard } \\
\text { currency }\end{array}$ & $\begin{array}{c}\text { Hard currency/ } \\
\text { Cash }(\%)\end{array}$ \\
\hline 1990 & 0,67 & 0,67 & 0,53 & 79 \\
1991 & 30,43 & 30,35 & 24,61 & 81 \\
1992 & 66,91 & 65,90 & 40,98 & 62 \\
1993 & 164,50 & 133,63 & 110,67 & 83 \\
1994 & 148,87 & 46,36 & 10,95 & 25 \\
1995 & 471,93 & 437,80 & 411,48 & 94 \\
1996 & 162,63 & 119,46 & 92,73 & 77 \\
1997 & 340,61 & 317,70 & 208,60 & 66 \\
1998 & 104,80 & 98,70 & 38,62 & 39 \\
1999 & 114,95 & 99,23 & 70,00 & 71 \\
2000 & 21,13 & 19,83 & 0,00 & 0 \\
Total: & 1628,2 & 1369,6 & 970,6 & 71 \\
\hline Source: Csáki, From Transition to Integration, 2002 & &
\end{tabular}

$7 \%$ of state assets were sold for compensation certificates distributed to victims of the fascist and communist regimes Hungarian privatization did not avoid scandals. For example, 8 out of 10 members of the privatization agency were forced to resign in 1994 after having been accused of corruption.

Until the mid 1995, SPA divested itself of $75 \%$ of the previous ownership, which nevertheless represented only 35\% of state property (Stojanov, 2004). The government still kept possession in gas distribution, railways, airlines, telecommunication, banks and chemical companies. This changed with the Bokros package, though. The government urgently needed to decrease fiscal deficits, and intensification of the privatization process was one of the ways to achieve this. It was decided that all stateowned property with the exception of railways, post office and national parks would be sold. The rest of the property for sale included The Savings Bank (OTP) and the main telecommunication company, among others. The amount of property for privatization reached HUF 1.3 trillion out of 1.6 trillion of the overall state ownership (Stojanov, 2004). A typical method was a direct sale to a foreign investor, which resulted in a huge inflow of foreign direct investment in this period. A growing role of foreign ownership can be seen in the following table. Until the end of 1997, the government sold property worth HUF 790 billion and its debt decreased from 86\% of GDP in 1995 to $60 \%$ in 1998 (Stojanov, 2004). 
Table 15: Ownership of Manufacturing Firms, \% of Registered Capital

\begin{tabular}{l|ccccc}
\hline Types of ownership & 1992 & 1993 & 1994 & 1995 & 1996 \\
\hline State & 55.2 & 39.2 & 29.3 & 19.9 & 14.4 \\
Municipal & 8.8 & 1.6 & 1.6 & 1.0 & 0.9 \\
Individual private & & 8.8 & 9.4 & 10.1 & 9.5 \\
Domestic corporate & 0.1 & 15.0 & 17.9 & 18.2 & 19.4 \\
Employee & 20.5 & 1.0 & 1.5 & 1.4 & 1.2 \\
Foreign & 3.6 & 30.9 & 37.1 & 46.7 & 51.1 \\
Cooperative & & 2.6 & 1.9 & 1.4 & 1.2 \\
Other & & 0.9 & 1.3 & 1.3 & 2.3 \\
\hline
\end{tabular}

Source: Stojanov, Hungary and Bosnia and Herzegovina: a success and a failure of transition, 2004

At the beginning of the transformation process, private sector quickly advanced in Central Europe, which can be seen in the following table. Take notice of the fact that Hungary achieved a 50\% share of the private sector in GDP in 1993 already.

Table 16: Private Sector Share in GDP (in \%)

\begin{tabular}{|c|c|c|c|c|c|c|c|c|c|c|c|c|}
\hline & ஓ & $\bar{\partial}$ & ลू & ڤ̆ & ஓे & ڤ̆ & ڤั & $\hat{a}$ & $\stackrel{\infty}{\circ}$ & बे & ঠ্ণ & 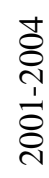 \\
\hline $\begin{array}{l}\text { Czech } \\
\text { Republic }\end{array}$ & 10 & 15 & 30 & 45 & 65 & 70 & 75 & 75 & 75 & 80 & 80 & 80 \\
\hline Hungary & 25 & 30 & 40 & 50 & 55 & 60 & 70 & 75 & 80 & 80 & 80 & 80 \\
\hline Poland & 30 & 40 & 45 & 50 & 55 & 60 & 60 & 65 & 65 & 65 & 70 & 75 \\
\hline
\end{tabular}

Source: EBRD: Selected economic indicators data, 26. 11. 2007.

\section{Economic Results}

We shall concentrate on the main economic indicators on the following pages, analyzing development of GDP, inflation, unemployment and several indicators of foreign relationships.

\section{Economic Growth}

Economic growth can be seen in the following figure. We can notice that similarly to other countries in central Europe, Hungary too suffered from transformation recession. The slower pace of the reforms (gradualism) did not help avoid the recession, and a visible slowdown after 1995 occurred here, too. But the general trend is positive. We should compare the results of HP filter during the communist regime with results after 1990. Hungarian economy was able to achieve growth around 3 or 4 percent after having overcome the transformation recession. 
Meanwhile, GDP per person followed a similar trajectory. The indicator declined at the beginning of the transformation process regardless of the pace of the reforms. In 1995, it reached the pre-recession level and steadily grew in the next years. It nearly doubled in comparison to 1989 by the end of 2004 .

Figure 7: Economic Growth After 1990 (in \%) and Its Trend Estimated by HP Filter

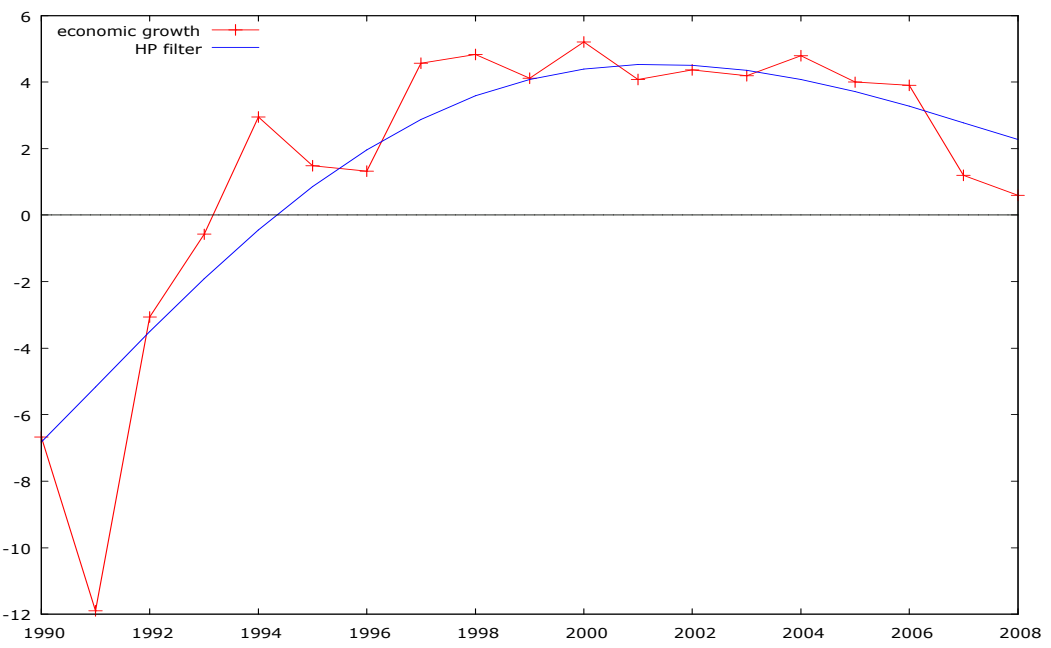

Source: Maddison, Historical Statistics - http://www.ggdc.net/MADDISON/oriindex.htm (11.10.2010)

Figure 8: GDP per Person in USD Based on Purchasing Power Parity (1989-2004)

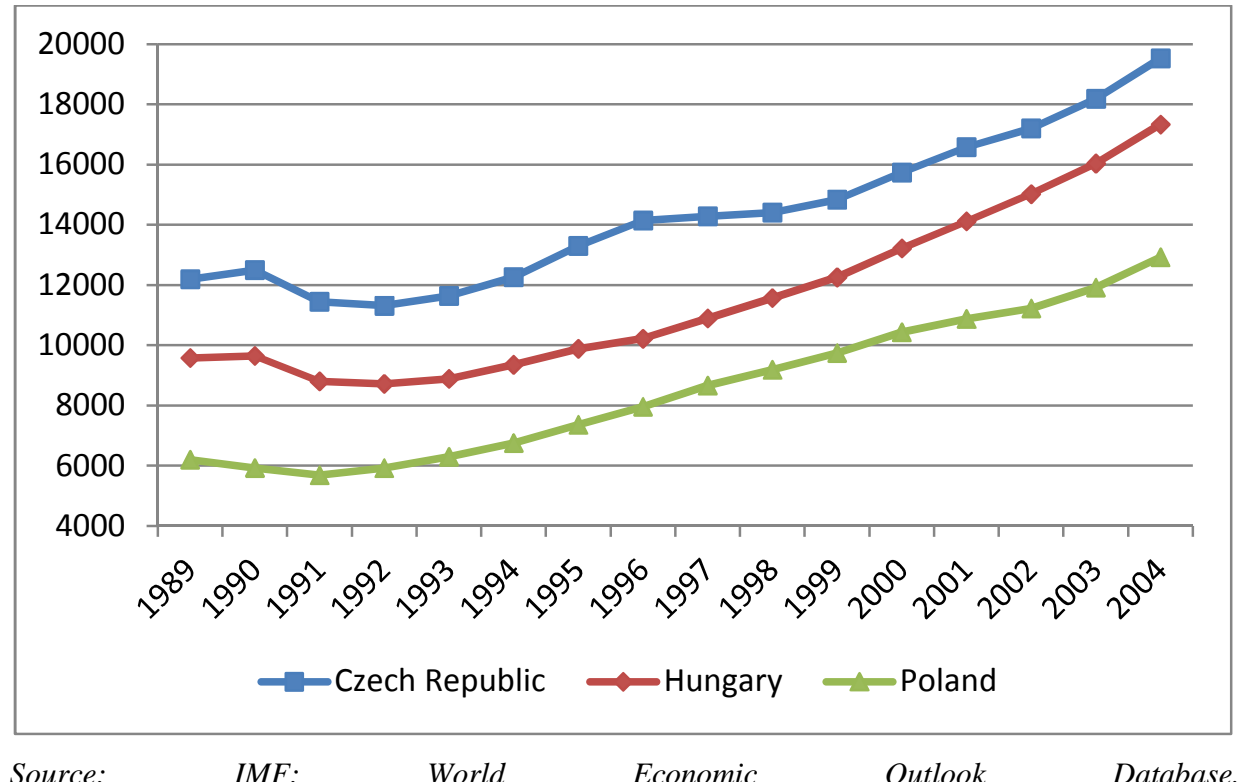

http://www.imf.org/external/pubs/ft/weo/2010/02/weodata/index.aspx (9. 10. 2010) 


\section{$\underline{\text { Structure of the Economy }}$}

Important changes took place in the role of the government in the economy. We can see a surprising development in Hungary, where the role of government (expenditure to GDP) in fact increased (from an already high level) at the beginning of the 1990s. And it declined only with the Bokros package. During the 1990s, the trend was generally declining in Central European countries. This changed in the new millennium when the share of the government increased in all countries.

Figure 9: Government Expenditure in Percent of GDP (1990-2004)

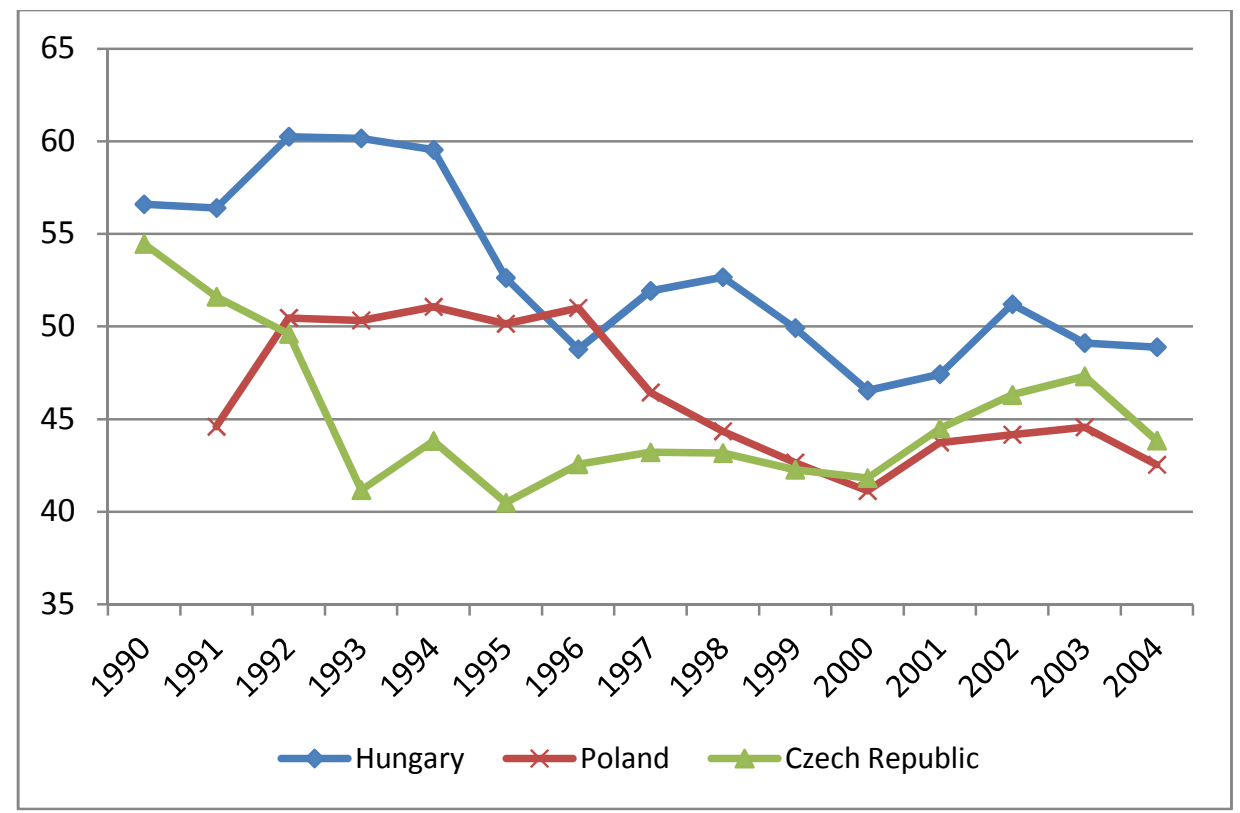

Source: EBRD: Selected economic indicators data, 26. 11. 2007.

Simultaneously, changes in the structure of the economy took place, as we can see in the following table. We should notice that the share of industry was very low in Hungary at the beginning of the transformation and even slightly increased during the period. Similarly to other countries of the region, the share of agriculture declined in Hungary, too. And the share of the last sector - services - had always been high and remained high level during the whole transformation period.

\section{Inflation}

Inflation was relatively low in Hungary during the first transformation decade. An important part of the goods in consumers' baskets had already been liberalized before 1990, and Hungarian politicians therefore did not have to carry out instant price liberalization. But Hungarian inflation was comparatively high in the following years. It was partly caused by the monetization mentioned above. Decline in inflation can be seen only at the end of the 1990s. Even then consumer prices increased more than 5\% per a year. The arithmetic average for the period between 1990 and 2003 reached nearly $18 \%$ (IMF, 2010). 
Table 17: Structure of Economy - Share of Industry (I), Agriculture (A) and Services (S) in \% of GDP

\begin{tabular}{|c|c|c|c|c|c|c|c|c|c|c|c|}
\hline & & $\begin{array}{l}2 \\
\stackrel{\infty}{=}\end{array}$ & ஓ & ळ & ๙ু & ڤ̆ & $\hat{a}$ & รे & ஓ্ণ & ஜ̊ণ & ষ্ণ \\
\hline \multirow{3}{*}{$\begin{array}{l}\text { Czech } \\
\text { Republic }\end{array}$} & $\mathrm{I}$ & & 36.7 & 37.9 & 39.4 & 33.3 & 35.9 & 35.5 & 37.5 & 38.2 & 40.0 \\
\hline & A & 6.3 & 8.2 & 5.6 & 4.6 & 4.7 & 5.0 & 3.9 & 3.7 & 3.4 & 3.3 \\
\hline & $\mathrm{S}$ & & 55.1 & 56.5 & 56.0 & 62.0 & 59.1 & 60.6 & 58.7 & 58.3 & 56.7 \\
\hline \multirow{3}{*}{ Hungary } & I & & & 21.0 & 20.4 & 23.1 & 25.0 & 26.7 & 26.6 & 26.7 & 26.5 \\
\hline & A & & & 7.8 & 6.5 & 5.9 & 5.8 & 5.3 & 5.0 & 4.2 & 6.1 \\
\hline & $\mathrm{S}$ & & & 71.2 & 73.1 & 71.0 & 69.2 & 68.0 & 68.4 & 69.1 & 67.4 \\
\hline \multirow{3}{*}{ Poland } & I & 44.1 & 44.9 & 40.2 & 34.0 & 32.1 & 30.7 & 29.7 & 29.5 & 29.6 & 30.8 \\
\hline & A & 11.8 & 7.4 & 6.8 & 6.7 & 5.6 & 4.5 & 3.2 & 3.2 & 2.6 & 2.5 \\
\hline & $\mathrm{S}$ & 44.1 & 47.7 & 53.0 & 59.3 & 62.3 & 64.8 & 67.1 & 67.3 & 67.8 & 66.7 \\
\hline
\end{tabular}

Source: EBRD: Selected economic indicators data, 26. 11. 2007.

Figure 10: Inflation, Average Consumer Prices (Percentage Change) 1980-2004

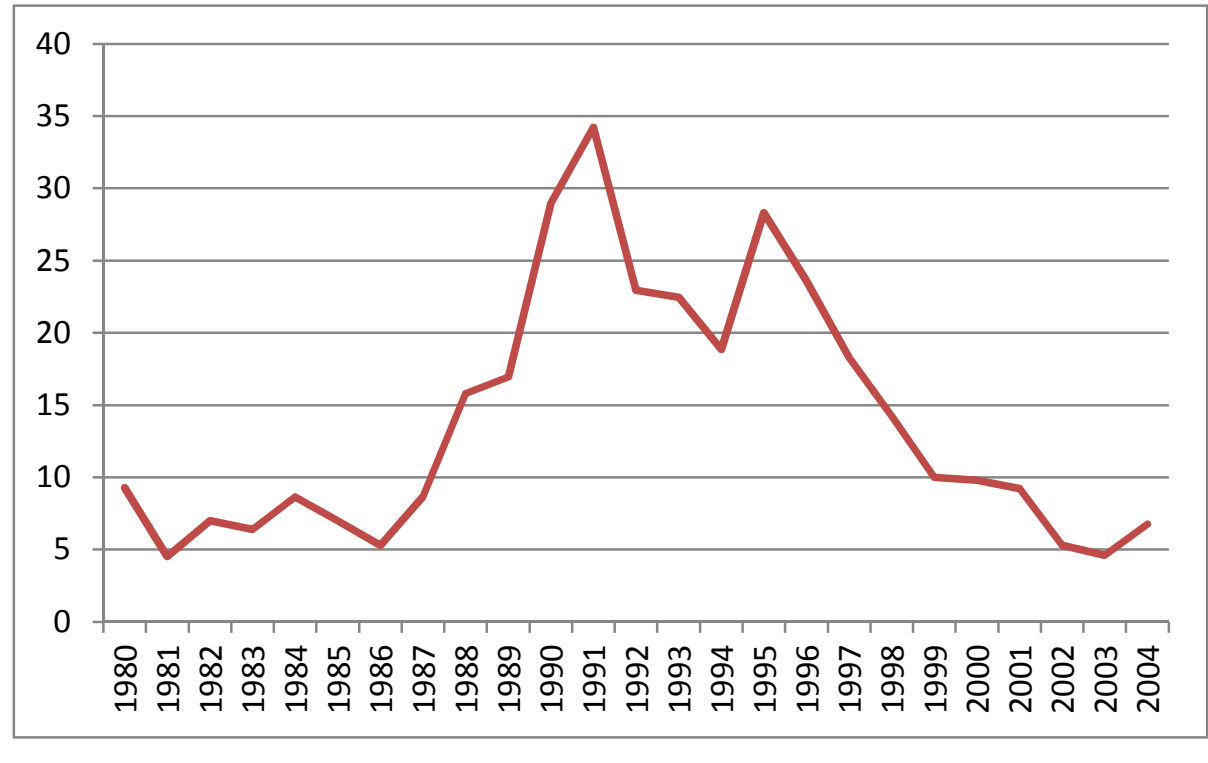

\section{Source: $\quad$ IMF: World Economic Outlook Database,} http://www.imf.org/external/pubs/ft/weo/2010/02/weodata/index.aspx (9. 10. 2010)

In accordance with expectations and economic theory of Balassa-Samuelson effect, prices went up more for non-tradable goods and services during the transformation period. An estimation of the price development of tradable and non-tradable goods can be seen in the following figure. 
Figure 11: Non-tradable/Tradable Inflation in Hungary (1991=1)

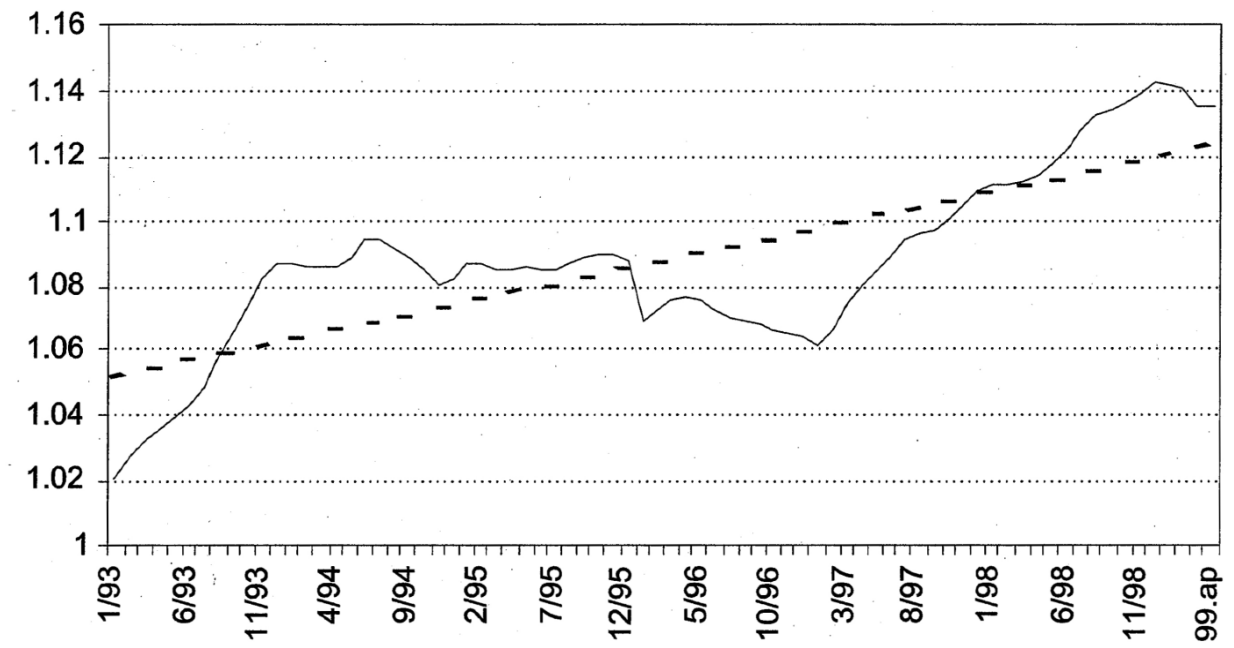

Source: Halpern, Neményi, Fiscal Foundations of Convergence to the European Union, 2001

Generally, economic rules are valid for transformation countries as well as for established market economies. The following figure depicts a connection between inflation and growth of money supply. We can see a nearly textbook relationship, in which countries with a higher difference between growth of money and growth of GDP have higher inflation. This development had an impact on the exchange rate regime and interest rates.

Figure 12: Inflation (Average Percentage Change of CPI) and Growth of Broad Money Minus Growth of Real GDP (in \%) Between 1993 and 2004

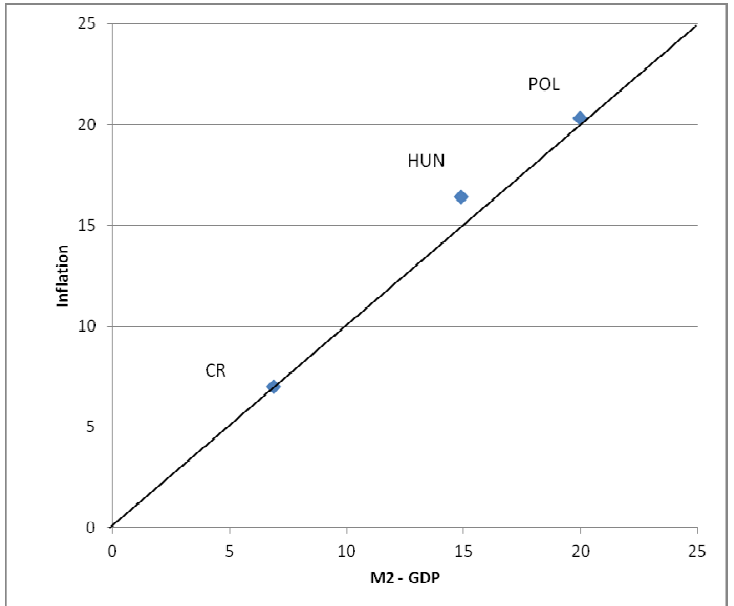

Source: EBRD: Selected economic indicators data, 26. 11. 2007. 


\section{$\underline{\text { Unemployment }}$}

Hungary was not spared growth in unemployment in the first years of transformation even though the country was actually following a more gradual approach. Within several years, unemployment achieved its maximum - around $12 \%$ of the labor force, after which it gradually declined. It is in contrast with the development in the Czech Republic, where unemployment rate was minimal until 1997 and grew only with the currency and economic crises in 1997. At that time, however, unemployment rate in Hungary had already been declining steadily. We should stress that in both of these countries, unemployment rate was very low in comparison to other post-communist countries - Poland being one of the examples, as we can see in the following figure. On the other hand, there was deep decline in employment in Hungary and thus the numbers are affected by it.

Figure 13: Unemployment Rate (\% of Labor Force) 1989-2004

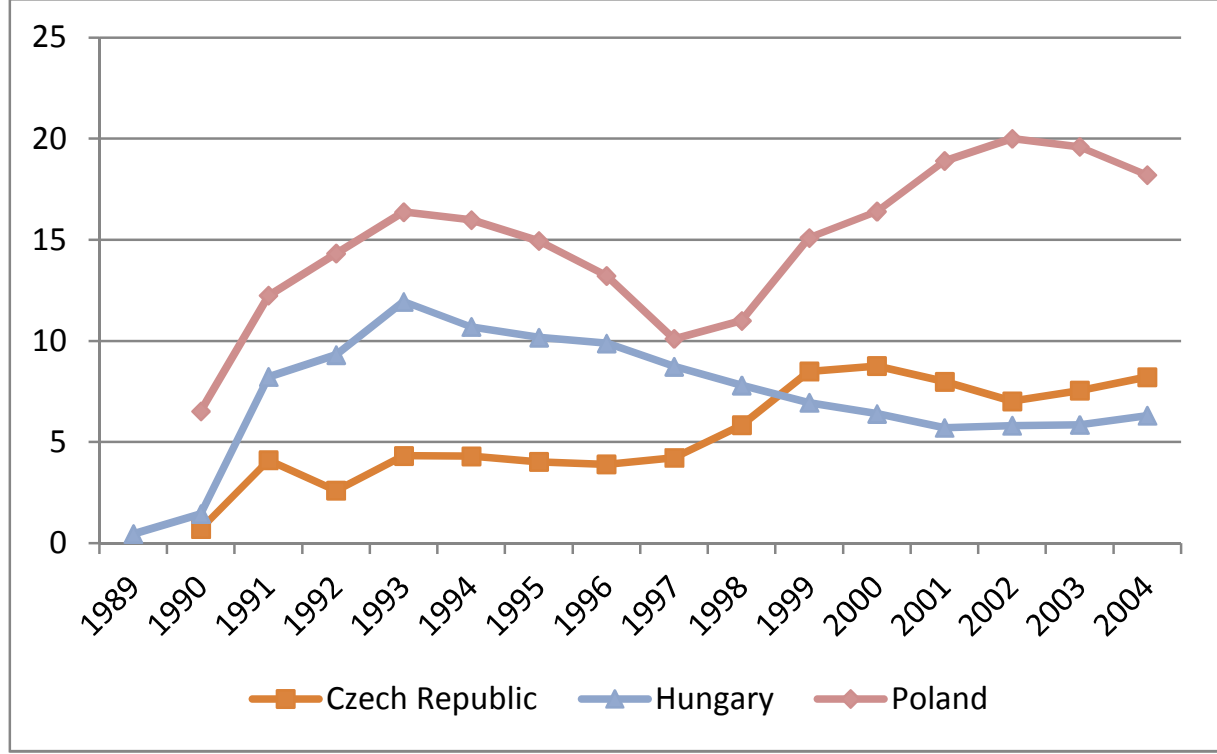

Source: EBRD: Selected economic indicators data, 26. 11. 2007.

External Relationship

We will discuss several aspects of external relationships on the following pages, concentrating on the development of international trade and foreign (direct) investment.

In the following table, we can see that Hungary was affected by disintegration of the Council for Mutual Economic Assistance (CMEA) relatively mildly. Hungarian exports declined by roughly one quarter, which was much less than in some of the other countries. The country generally followed the path to liberalization of international trade as other countries of the Eastern bloc. In 1990, tariffs declined and quotas on consumption goods were abolished. 
Table 18: Exports to CMEA Markets (mil. USD)

\begin{tabular}{l|cccccc}
\hline & 1989 & 1990 & 1991 & 1992 & 1993 & $\begin{array}{c}\text { \% decline } \\
\text { between 1989 } \\
\text { and 1993 }\end{array}$ \\
\hline Czech Republic* & 5,103 & 3,422 & 2,045 & 1,103 & 1,009 & 80.2 \\
Bulgaria & 7,967 & 5,887 & 1,892 & 1,103 & 1,009 & 87.3 \\
Hungary & 4,009 & 2,933 & 2,710 & 2,981 & 3,122 & 22.1 \\
Poland & 4,395 & 4,000 & 1,799 & 1,476 & 1,461 & 66.8 \\
Romania & 3,890 & 2,083 & 1,089 & 702 & 720 & 81.5 \\
Slovakia & 1,827 & 1,169 & 1,376 & 1,200 & 1,130 & 38.1 \\
\hline
\end{tabular}

* without inter Czechoslovak trade

Source: Jonáš, Ekonomická transformace v České republice, 1997; own calculation

Hungarian trade quickly re-orientated towards western markets. EU-15 had already had a $34 \%$ share of Hungarian exports as early as in 1989. This number rapidly increased to $50 \%$ in 1991 and $70 \%$ in 1997 . The role of goods in the exports into the EU had grown as well - from 55\% in 1989 to 85\% 1997 (Stojanov, 2004). Germany became Hungary's main trading partner, just as it became for the other Central European countries (we can see the state in 2003 in the subsequent table).

Table 19: The Share of the Main Trading Partners in 2003 (in \%)

\begin{tabular}{lc|lc}
\hline Imports & \% share & Exports & \% share \\
\hline Germany & 24.5 & Germany & 33.9 \\
Italy & 7.1 & Austria & 8.1 \\
China & 6.9 & Italy & 5.8 \\
Austria & 6.3 & France & 5.8 \\
Russia & 6.2 & United Kingdom & 4.6 \\
France & 4.8 & Netherlands & 4.1 \\
Japan & 4.2 & USA & 3.1 \\
USA & 3.2 & Poland & 2.3 \\
Poland & 2.8 & Czech Republic & 2.1 \\
United Kingdom & 2.7 & Slovakia & 2 \\
Czech Republic & 2.4 & Russia & 1.5 \\
Netherlands & 2.2 & Japan & 0.7 \\
Slovakia & 1.9 & China & 0.4 \\
\hline
\end{tabular}

Source: Hungarian Central Statistical Office,

http://statinfo.ksh.hu/Statinfo/themeSelector.jsp?page $=2 \&$ szst $=Q K T(29.12 .2010)$

Overall, Hungarian economy deeply integrated itself into the world economy, as we can see in the following figure. The share of exports and imports to GDP increased from $60 \%$ in the first half of the 1990 s to more than $160 \%$ before the last economic crisis. 
Figure 14: Exports and Imports as Percentage of GDP in Hungary and Poland (in \%)

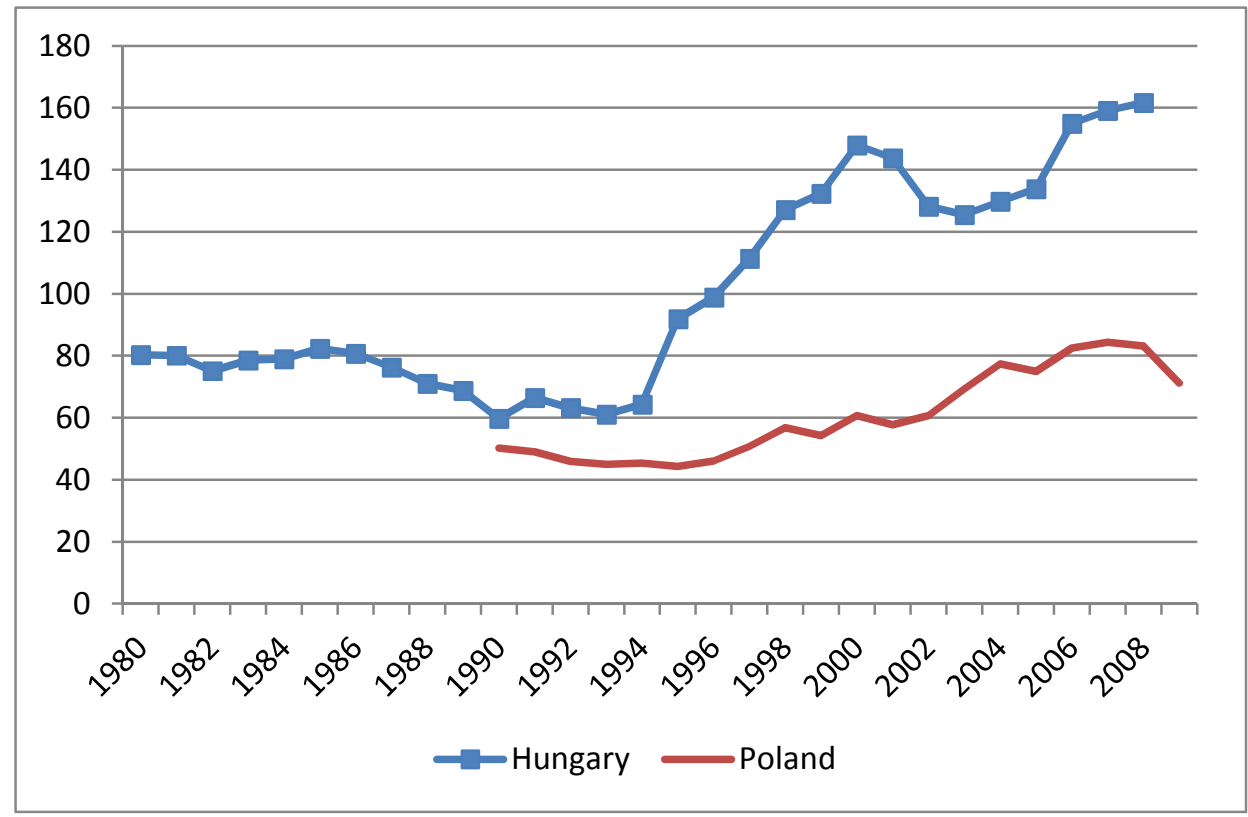

Source: The World Bank, Doing Business, www.doingbusiness.org, 1.12.2010

Figure 15: Current Account to GDP (\%) 1990 - 2004

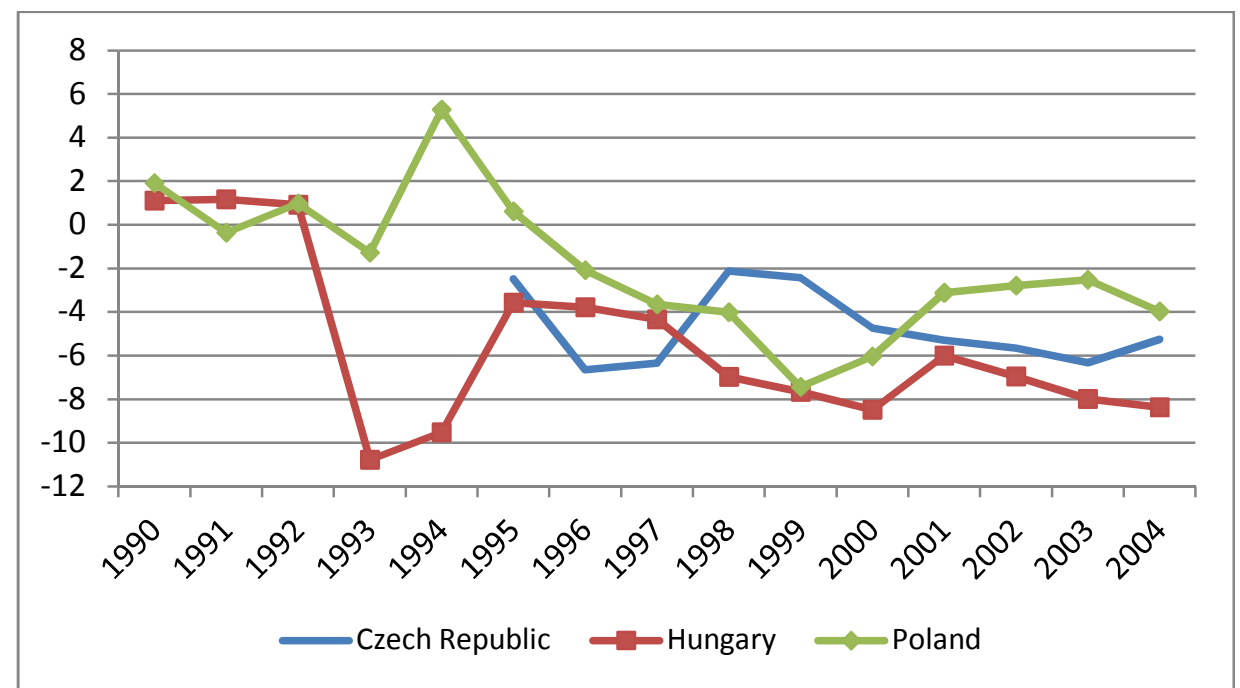

Source: IMF: World Economic Outlook Database,

http://www.imf.org/external/pubs/ft/weo/2010/02/weodata/index.aspx (9. 10. 2010) 
We have already mentioned problems with current account that Hungary experienced in the middle of the decade. The Bokros package solved these problems but the imbalance started to grow again in the new century. These problems were not deemed to be as severe as in the middle of 1990 s but contributed to currency problems during the world economic crisis at the end of the first decade.

Inflow of foreign direct investment is the second aspect of international relations that we would like to discuss. We have already mentioned that Hungary had already had a good starting position in this field because of its advance during the 1980s. This led to a relatively high inflow of FDI in the first years of the transformation already, and Hungary was one of the leaders among the post-communist countries, which we can see in the following figure.

Figure 16: Cumulative FDI Inflows per Capita 1990-2004 in USD

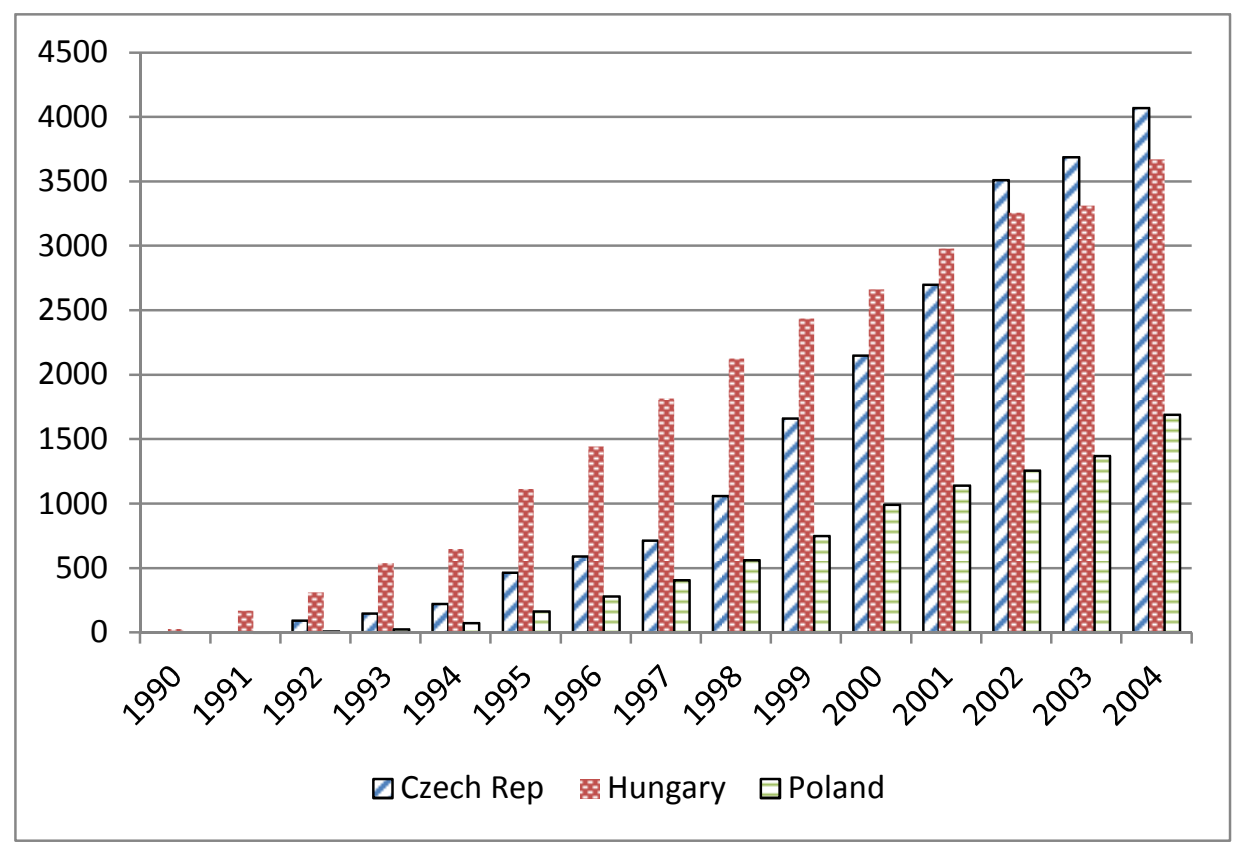

*- there are no data for the Czech Republic in 1990 and 1991, and for Poland in 1990

Source: EBRD: Selected economic indicators data, 26. 11. 2007.

Economic problems in the middle of the first decade resulted in increasing privatization efforts and installing of investment stimulus. These measures facilitated even higher inflow of the FDI in the second half of the 1990s. The comparison with the Czech Republic can be seen in the following table. 
Table 20: FDI in the Czech Republic and Hungary 1990 - 2000 in \$ per Person

\begin{tabular}{|c|c|c|c|c|c|c|c|c|c|c|c|}
\hline & ஓㅇ & a & ๙ૂ & ๙̊ & ஓ & ฉ̊ & ๖ั & $\hat{a}$ & $\stackrel{\infty}{\stackrel{\alpha}{\alpha}}$ & 天े & $\underset{\overbrace{}}{\stackrel{\overbrace{}}{8}}$ \\
\hline HUN & 30 & 141 & 142 & 227 & 112 & 435 & 223 & 214 & 201 & 196 & 196 \\
\hline C.R. & 13 & 50 & 97 & 63 & 84 & 248 & 138 & 126 & 361 & 615 & 447 \\
\hline
\end{tabular}

Generally speaking, the role of foreign entities in Hungarian economy was growing. The main investors came from Germany and the USA. Companies with foreign capital had been already generating $47 \%$ of all sales, $29 \%$ of employment and $60 \%$ of exports in 1996. The exports figure increased to 73\% in 1997 (Berend, 2009). The importance of the foreign companies in Hungary and other Central European countries can be seen in the following table. Stock of FDI corresponded to one third of Hungarian GDP in 1998 (Stojanov, 2004).

Table 21: Share of Foreign Companies in Industrial Sector at the End of the 1990s

\begin{tabular}{c|cccc}
\hline & Employment & Investment & Sales & Exports \\
\hline Czech Republic & 27 & 53 & 42 & 61 \\
Hungary & 47 & 82 & 73 & 89 \\
Poland & 29 & 63 & 49 & 59 \\
\hline
\end{tabular}

Source: Berend, From the Soviet Bloc to the European Union, 2009

\section{Conclusion}

We have tried to provide the reader with a view of the main steps in the economic development during the interesting period of economic transformation.

We argued that Hungary had achieved (in the view of the author) very good results in this period. First of all, the overall framework of the economy obviously changed, which was proven by the country accession to the EU in 2004. Simultaneously, GDP per person nearly doubled during the period. The ability of the economy to grow improved and the trend was positive (on the contrary to the previous period). As a consequence, Hungarian economy was able to start closing the gap on the developed countries. Most of other economic indicators developed positively as well. Moreover, it should be mentioned, too, that Hungarian companies managed to stand up to competitive pressures in the EU.

On the other hand, though, we have seen that the development in Hungary was not straightforward. The country suffered from transformation recession just as the other countries of the Eastern bloc even though its starting conditions were significantly better in some aspects. The half-hearted economic reforms in the first years of the transformation led to economic imbalances that were cured by tough economic measures in the form of the Bokros package. This development could serve as a model case for countries (like Greece today) which are postponing tough reforms. Unfortunately, Hungarian economy was not able to avoid other problems. And some of 
the crucial problems of the economy at the end of the 2000s had their roots in the transformation period. Predominantly, it was the case of growing household indebtedness in foreign currencies that later on, after the depreciation of the Hungarian forint, contributed to solvency problems. A persisting and relatively high level of government debt that again deepened in the subsequent period and brought the country on the brink of bankruptcy during the world financial crisis was another cause of the trouble. Today, nonetheless, it seems that Hungary managed to overcome these problems - similarly as it did in the middle of the 1990s.

We would like to argue that the transformation process was complicated and difficult but that the country was able to achieve the main goals of the transformation process. Unfortunately, some of the mistakes partially spoilt the overall view.

\section{References}

ALLEN, M., HAAS, R. (2001). The Transition in Cetral and Eastern Europe: The Experience of Two Resident Representatives. IMF Staff Papers. 48 (Special Issue).

BEREND, I., T. (2009). From the Soviet Bloc to the European Union. Cambridge University Press. ISBN: 978-0-521-49365-9.

BETHKENHAGEN, J. (1989). Hungary in GDR and Eastern Europe. In the German Institute for Economic Research (ed.). Handbook. Avebury: German Institute for Economic Research. ISBN 0-566-05634-8.

BORISH, S., M., NOËL, M. (1996). Private Sector Development During Transition. World Bank Discussion Papers. number 318.

CSÁKI, G. (2002). From Transition to Integration: FDI-Inflows into Hungary, a Success Story of the Hungarian Transition. In Hanori, B. (ed.) Scientific Proceedings Budapest: College of Management. ISBN 1585-8960.

DABROWSKI, M. (2003). Disinflation Strategies and thein Effectiveness in Transition Economies in Disinflation. In Dabrowski M. (ed.), Transition Economies. Budapest, New York: CEU Press. ISBN 963-9241-29-6.

EARLE, J., S., ESTRIN, S. (1996). Employee ownership in transition. In Frydman R., Gray Ch. W., Rapaczynski A. (ed). Corporate governance in Central Europe and Russia . Budapest: CEU Press. ISBN: 1-85866-036-X.

EARLE, J., S., FRYDMAN R., RAPACZYNSKI, A., TURKEWITZ, J. (1994). Small privatization. Budapest: Central European University Press. ISBN 1-85866-006-8.

EUROPEAN BANK FOR RECONSTRUCTION AND DEVELOPMENT (EBRD) (2007, November 26). Selected economic indicators data. Retrieved (2010, November 26 2007, from http://www.ebrd.org/country/sector/econo/stats/index.htm.

EUROSTAT: ec.europa.eu/eurostat (15.4.2013)

EYAL, G., SZELÉNYI, I., TOWNSLEY, E. (1998). Making Capitalism Without Capitalist: Class Formation and Elite Struggles in Post-Communist Central Europe. London Verso. 
FRAIT, J., KOTLÁN, V. (2000). Macroeconomic stabilization and macroeconomic policy In Cueto C.de, Hájek L. (ed.), Politics and economics in the Czech transition. Gaudeamus. ISBN 80-7041-232-1.

GABRISCH, H., HÖLSCHER, J. (2006). The Successes and Failures of Economic Transition. Palgrave. ISBN: 978-1-4039-3493-2.

HALPERN, L., NEMÉNYI, J. (2001). Fiscal Foundations of Convergence to the Euroepan Union. In Blejer M., I., Škreb M. (ed.). The Hungarian Economy towards EU Accession in Transition. Cambridge Massachusetts, London: The MIT Press. ISBN: 0262-02505-1.

HANLEY, E., KING, L., JÁNOS, I., T. (2002). The State, International Agencies, and Property Transformation in Postcommunist Hungary. American Journal of Sociology. 108 (1). Pp. 129-167.

HOLMAN, R. (2000). Transformace české ekonomiky. Praha: Centrum pro ekonomiku a politiku. ISBN 80-902795-6-2.

HUNGARIAN CENTRAL STATISTICAL OFFICE (2010 December 29). Statistical info. Retrieved December $29, \quad 2010$ from http.//statinfo.ksh.hu/Statinfo/themeSelector.jsp?page=2\&szst=QKT.

CHVOJKA, P., ZEMAN, K. (2000). Tendence dosavadního vývoje zemí střední a východní Evropy. Politická ekonomie. (6).

INTERNATIONAL MONETARY FUND - IMF: International financial statistics, http://elibrary-data.imf.org/ (15. 5. 2013)

INTERNATIONAL MONETARY FUND - IMF (2010, December 9). World Economic Outlook Database. Retrieved December 9, 2010 from http.//www.imf.org/external/pubs/ft/weo/2010/02/weodata/index.aspx.

JONÁŠ, J. (1997). Ekonomická transformace v České republice. Praha: Management Press. ISBN 80-85943-22-0.

JONÁŠ, J. (2003). Mad'arský př́íklad, ale i varování. Hospodářské noviny. 17. 2. 2003.

KENDE, P. (1993). Rovnostářské a etatistické dědictví ve střední a východní Evropě in CEFRES, C. du. (Ed.), Politická a ekonomická transformace v zemích střední a východní Evropy. June, number 3.

KLAUS, V., TOMŠÍK, V. (2007). Makroekonomická fakta české transformace. Brno: NC Publishing. ISBN 978-80-903858-1-8.

KORNAI, J. (1996). Paying the Bill for Goulash-Communism. Hungaria Development and Macro Stabilization in Political-Economy Perspective. Social Research. 63 (4).

LAKI, M. (1993). Hungarian survey. In Winiecki J., Kondratowicz, A. (ed.). The macroeconomics of transitiv. London and New York: Routledge. ISBN 0-415-09167-5.

LAVIGNE, M. (1992). The Economics of Transition, New York: St. Martin’S Press Inc., 2nd edition. ISBN: 0-333-75416-6. 
MADDISON, A. (2010, October 11). Historical Statistics. Retrieved October 11, 2010, from http.//www.ggdc.net/MADDISON/oriindex.htm.

MAGYAR NEMZETI BANK (2004). ANNUAL REPORT 2003. Budapest. ISSN 12166197.

MAGYAR NEMZETI BANK (2010, October 11). Official devaluations of the forint, 1990-2003. $\quad$ October $11, \quad 2010, \quad$ from http.//english.mnb.hu/Root/ENMNB/Statisztika.

MAGYAR NEMZETI BANK (2005). Quarterly Report on Inflation. February 2005. ISSN 1419-2926.

MARKIEWICZ, M. (2003). Fiscal Policy and Desinflation in Transition Economies in Disinflation in Transition Economies. In Dabrowski M. (ed.), Transition Economies. Budapest, New York: CEU Press. ISBN 963-9241-29-6.

MEDVEC, S. E, STONE, C. S. (1990). Approaching Convertibility in Eastern Europe and the Soviet Union. Review of Business. Vol. 12.

NESTOR, S., THOMAS, S. (1995). Systematic Privatization and Restructuring in EastCentral Europe. In Hardt J.P., Kaufman R.F., Sharpe M.E. (ed.). East-Central European Economies in Transition. Armonk. ISBN. 1-56324-613-9.

The PEW: Global Attitudes project, www.pewglobal.org, published 2. 11. 2009, (15. 5. 2013)

SOÓS, K., A. (2011). Politics and Policies in Post-Communist Transition, BudapestNew York: CEU Press. ISBN: 978-963-9776-85-2.

SRHOLEC, M. (2001). Vybrané aspekty makroekonomického vývoje v Mad'arsku po roce 1995. Politická ekonomie. (6).

STOJANOV, D. (2004). Hungary and Bosnia and Herzegovina. a success and a failure of transitiv. Working Papers Institute for World Economics., No. 149.

The World Bank, Doing Business, www.doingbusiness.org, 1.12.2010

TOMŠÍK, V. (1998). Makroekonomický vývoj České republiky, Mad’arska a Polska v letech 1990-1996. Politická ekonomie. (4)

TOMŠÍK, V. (1992). Vliv měnové a kurzové politiky na reálnou ekonomiku v Mad'arsku, Polsku a České republice. Politická ekonomie. (3).

VINTROVÁ, R. (1992). Možnosti oživení, Ekonom. (17).

WINIECKI, J. (1993). Regional surfy. In Winiecki J., Kondratowicz A. (ed.). Regional survey. London and New York: Routledge. ISBN 0-415-09167-5.

WORLD BANK (2008). Regular Economic Report PART II. Special Topic January 2008. Retrieved February $13, \quad 2012$ from http.//siteresources.worldbank.org/ECAEXT/Resources/258598-

1202152569208/EU8+2_SpecialTopic_Jan08.pdf. 